\title{
BIJDRAGE TOT DE GESCHIEDENIS VAN HET EILAND BANGKA,
}

\author{
(naar een Maleisch Handschrift)
}

DOOR

F. S. A. DE CLERCQ.

Omtrent de vroegste geschiedenis van het eiland Bangka is zoo goed als niets bekend. In de Javaansche kronieken wordt hier en daar in korte bewoordingen van Bangka melding gemaakt, zonder dat daaruit met zekerheid het een of ander is af te leiden en de zeer verspreide berichten van westersche schrijvers zijn al even onbepaald. Als eenigste bron blijft derhalve over datgene, wat Thomas Horsfield te Palembang bijeenbracht en in The Journal of the Indian Archipelago and Eastern-Asia van 1848 werd opgenomen, en dat door Prof. P. J. Veth in den Jaargang 1850 van het Tijdschrift voor Nederlandsch-Indië, Deel I, blz. 192 vlg., is vertaald en van vele aanteekeningen voorzien.

In hoofdzaak dagteekent het daarin medegedeelde echter van den tijd, dat Bangka onder Palembang kwam te staan; maar bovendien berust dit louter op gegevens te Palembang verkregen en is derhalve niet geheel van eenzijdigheid vrij te pleiten. Daargelaten nog dat Horsfield zelf begint met de verklaring, dat aan deze grootendeels mondelinge overleveringen geen te groote waarde dient gehecht.

Eenige jaren geleden voor dienstzaken te Muntok vertoevende, leerde ik aldaar kennen den onderwijzer aan de inlandsche school, Hadji Idris; iemand, die hoezeer voor deze betrekking volstrekt niet opgeleid, haar toch niet onverdienstelijk vervulde. en bovendien door zijn uitgebreide kennis der Maleische taal en hoogen leeftijd in de schatting zijner landgenooten zeer goed stond aangeschreven. Bij nadere kennismaking gaf hij mij een handschrift in het Maleisch over de geschiedenis van Bangka, door hem samengesteld, waarvan ik toenmaals wel een gedeelte las, mar dat door verplaatsing als 6 e Volgr. I. 
anderszins onder andere stukken bedolven raakte en eerst onlangs door mij werd teruggevonden.

Eene vergelijking met bet weinige, dat wij van Bangka weten, overtuigde mij spoedig, dat in het bewuste H. S. veel onzekers wordt opgehelderd, zij het ook niet op zuiver historische gronden, en dat het blijken gaf van met tal van bijzonderheden rekening te hebben gehouden; zoodat het, bij gemis van andere gegevens, met veel waarschijnlijkheid een der waarheid getrouw, tamelijk nauwkeurig overzicht geeft van hetgeen in opvolgende eeuwen te Bangka voorviel. Dat zulks zich bepaalde tot groote trekken en op echt inlandsche wijze vaak kleinigheden als hoofdzaken worden behandeld, ligt te zeer voor de hand om eene nadere verklaring te behoeven.

Daar het, met uitzondering der instructies voor den Rangga en de Patih's, geen stuk is, waarbij raadpleging van den tekst noodig kan heeten, zoo wordt alleen een eenigszins vrije vertaling gegeven, waar noodig van ophelderende noten voorzien; terwijl het H. S., ter mogelijke raadpleging door belangstellenden, aan de Bibliotheek van het Instituut is afgestaan. 
De bewerker van het H. S. begint met de opgave van hetgeen in den mond des volks over het ontstaan van het eiland Bangka tot heden voortleeft en dat op het volgende neerkomt.

Bejaarde lieden ter hoofdplaats Muntok ${ }^{1}$ bezitten dienaangaande twee overleveringen.

Volgens de eerste vertrok uit Djohor eene groote prauw, bemand met vele mannen en vrouwen, onder de leiding van Naehoda Ragam. Onderweg werd die prauw overvallen door een fellen wind en zware deining, waarbij de Nachoda omkwam, getroffen door een naald zijner vrouw. Daar echter vele van de opvarenden in de meening verkeerden, dat hij vermoord was, ontstond er een oproer, dat menigeen het leven kostte. De prauw, aan wind en storm overgelaten, strandde of verging. Deze prauw nu werd het eiland Bangka; hare masten veranderden in bergen; een schuitje werd het eiland Billiton ${ }^{2}$ en een gedeelte der kajuit Batoe Balai ${ }^{3}$; de kookplaats werd een eiland, genaamd Semboeang Dapoer ${ }^{4}$, nabij Toboali. De overlevenden waren de eerste bewoners van Bangka. ${ }^{5}$

${ }^{1}$ In het H. S. staat natuurlijk overal ${ }^{\varsigma}$ gii. $_{\infty}=$ MĕNTos $^{s}$, overeenkomstig de inlandsche uitspraak.

2 In het H. S. natuurlijk بلبتوغ = Blttoeng.

${ }^{3}$ Batoe Bali is een dorp nabij de hoofdplaats Muntok aan de rivier Dahin. TEYsmann deelt mede, dat er een geheel bosch van Quercus-soorten gevonden wordt ' (Natuurkundig Tijdschr. v. N. I. Dl. XXXIV).

4 Dit eiland komt op de kaarten niet voor; wel een kampong Sabang nabij de in den tekst genoemde plaats en bij Ullmann $\mathrm{Sab}$ ang of Toboali.

Ten overvloede wordt herinnerd, dat Bangka is verdeeld in negen mijndistricten, nl. in het noordwesten: Djeboes en Muntok; in het midden van het noorden naar het zuiden: Belinjoe, Soengei-Lijat, Merawang, Pangkal-Pinang en Soengei-Selan; in het zuidoosten: Koba en Toboali. Voor het inlandsch bestuur zijn deze nog gesplitst in onderafdeelingen. De eerste worden bestuurd door hoofden met den titel van Demang, de laatsten door anderen met dien van Batin.

5 In het werk "Het eiland Bangka en zijne aangelegenheden" door H. M. LANGE wordt opgegeven, dat dit eiland ook $\mathrm{C}$ hina-Batta heet. Ik heb de beteekenis hiervan niet kunnen ontdekken; zelfs GroENEVELDT vermeldt dien 
Naar de tweede overlevering ontstond Bangka door een strook lands, die zich afscheidde van Djohor, waarom genoemde Nachoda Ragam een groot vaartuig bouwde te Penggantingan in Djohor. Toen hij dat vaartuig te water wilde laten, groef hij een sloot om het zeewater te doen binnenstroomen en het zoo vlot te krijgen. Nadat het vaartuig in zee was, bleef de gleuf met water bestaan. Vervolgens ging Nachoda Ragam onder zeil met allerlei schepelingen, waarvan enkelen hunne vrouwen en kinderen medenamen. Eenigen tijd onderweg zijnde, overviel hen een hevige storm met hooge zeeën, die dagen lang duurde. Het vaartuig dreef af, de Nachoda kwam daarbij om en er barstte een oproer onder de opvarenden uit. De pas gegraven gleuf te Penggantingan werd breeder en afgescheiden en alzoo ontstonden de eilanden Bangka, Billiton, Singkep en andere daartusschen gelegen kleine eilanden. Afdrijvende strandde het vaartuig op het eiland Bangka en de overlevenden gingen er aan wal en waren de eerste bewoners.

Luidens het verhaal van lieden van Maras ' ontstond Bangka uit een prauw.

De zoon van een Boegineeschen vorst, genaamd Sri Gading, trok uit zijn land om een vrouw te zoeken. Rondreizende had hij gekregen een Arabische vrouw, een Maleische, een Chineesche en vier Javaansche vrouwen. Zijn vaartuig dreef af, strandde aan den voet van den berg Kalidang en maakte het eiland Bangka grooter; de masten werden bergen en een stuk er van werd Billiton. Sri Gading keerde naar zijn land terug; de opvarenden bleven achter en werden bewoners van Bangka. Sinds vroeger waren er twee Palembangers op den berg Kalidang, die bij hun dood in boeloh-aoer ${ }^{2}$ ver-

naam niet in zijn "Notes on the Malay Archipelago". Waarschijnlijk is deze overgenomen uit de "Schets van het eiland Bangka” in het Tijdschr. v. $\mathrm{Neerl}$. Indie, ja arg. 1846 , alwaar dat $\mathrm{C}$ hin a-Batt a eveneens zonder nadere omschrijving voorkomt; of wel van de kaart van LINSCHOTEN, door prof. VETH in zijne vertaling aangehaald. Op blz. 59 van zijn "Reijsgheschrift van de Navigatien der Portugalopsers in Orienten" noemt L. het eiland evenwel B anca zonder meer.

1 Maras is de hoogste berg van Bangka (2617 Rijnl. v.), gelegen aan den zuidwestelijken inham van de Klabat-baai. In den loop van dit verhaal is herhaaldelijk sprake van de drie toppen van dezen berg, maar in het $\mathrm{T}$ ijdschr. N. I. ja arg. 1846 wordt hij als tweepuntig beschreven. Dr. CROockewit, die den berg in 1849 of 1850 beklom, noemt slechts één top. (Zie zijn Verslag, uitgeg. door het Kon. Inst. v. d. T., L. en V. v. N. I).

? Boeloh aoer is een dikke, gladde bamboesoort, wetenschappelijk nog niet nader gedetermineerd. 
anderden; deze konden goed praten met een schoone stem en waren de teruggeblevenen door hunne plaatselijke kennis behulpzaam.

De lieden van Pandji, Belinjoe en de Seka ' verhalen, dat het eiland Bangka is ontstaan uit een vaartuig, bemand met Boegineezen, onder aanvoering van een vorstenzoon, met name Aroeng ${ }^{2}$, die zijn land verliet omdat hij werd weggejaagd door zijn vader, daar hij bloedschande wilde plegen met zijn zuster. Daarom vertrok hij met een vaartuig, vervaardigd van een houtsoort, bangka geheeten. Hij zeilde uit met veel menschen. Het vaartuig verongelukte en zonk, waaruit een eiland ontstond, dat Bangka genaamd en door de opvarenden bevolkt werd. De Djoeragan ging met zijn bloedverwanten in een bootje naar Java en kwam aen Arabisch schip tegen, aan welks hoofd hij de achtergeblevenen aanbeval. Deze zorgde voor hen en gaf het eiland later over aan den vorst van Java. Na verloop van tijd werden de Bangkaneezen beoorloogd door de Orang Moloekoet ${ }^{3}$, maar zij kregen geen hulp van den vorst van Java, wel van den vorst van Djohor; reden waarom Bangka door dezen geregeerd werd, om vervolgens onder Bantam en eindelijk onder Palembang te geraken.

Volgens de lieden van Njaloe, Bagoeng, Geroenggoeng en Djeroek ${ }^{4}$ ontstond het eiland Bangka uit een vaartuig of vlot, dat van Arabië kwam. Afgedreven en vastgeraakt werd dat vlot het eiland Bangka, met de menschen die er op waren. Alleen het opperhoofd, wiens vlot verging, kwam op een $\mathrm{kadjang}^{5}$ te Palembang,

1 Belinjoe is een mijndistrict en $\mathrm{Pandji}$ een kampong, gelegen aan het gelijknamige riviertje, dat uitmondt in de Klabat-baai, De Seka zijn lieden, die op zee zwerven en met hun huisgezin in prauwen wonen, zonder vaste verblijfplaats op den vasten wal. Zij beweren af te stammen van de $\mathrm{raj}$ at of het volk in Djohor (zie hierachter). Zij leven voornamelijk van de vischvangst en het verzamelen van agar-agar, een zeewier met geleiachtig slijm, welke zij tegen andere levensmiddelen inruilen. Op Bangka houden zij zich vooral op in de Klabat-baai en te Koerow aan de westkust. Zie over hen nog Ecoma Verstege in Tijdschr. Bat. Gen. Dl. XXIV, blz. 201.

2 Aroe of Aroeng is een Boegineesch woord, dat vorst beteekent.

$s$ In den tekst opgehelderd door "geringe lieden die uit zee kwamen". Ik vind dezen naam nergens vermeld, en wellicht waren het zeeroovers van Borneo, want dáár is een rivier Meloeko in het landschap Tanah-Laoet. Iets verder spreekt de Schr. van Meloekoet of Batak, omdat zij menschen aten, welke bijvoeging vrij willekeurig schijnt.

4 Geroenggoeng is een onderafdeeling van het district Soengei-Lijat en Djeroek van het district Merawang. Njaloe en Bagoeng zijn kampongs op den weg van Muntok naar Pangkal-Pinang.

$5 \mathrm{Kadjang}$ is matwerk tot bedekking van daken, wanden, prauwen, enz. 
op een berg, genaamd Boekit Segoentang. Van dezen stammen af de Maleische vorsten opgegeven in de Djohorsche geslachtslijst van Sang Soeperba of Sri Tri Boeana '.

Volgens de lieden van Boekit ${ }^{2}$ ontstond het eiland Bangka uit een vlot, afgedreven van Arabië, waarmede slechte lieden verbannen werden. De helft van dat vlot zonk en dadelijk kwam er een eiland of verheven rif te voorschijn. Dit werd het eiland Bangka en de opvarenden zijn bewoners.

Volgens de lieden van Koba ${ }^{3}$ ontstond het eiland Bangka uit een vaartuig met Javanen, wier aanvoerder Genderesah heette. In dien tijd bestond Bangka slechts uit den berg Maras. Genderesah huwde met een vrouw, welke zich op dien berg bevond en Sri genaamd was, onder belofte dáár te zullen blijven. Maar hij verbrak zijn woord en dwong zijn echtgenoote naar zijn eigen land terug te keeren. Daarom kreeg zijn vaartuig een ongeluk, barstte uiteen en diende om het eiland Bangka te vergrooten, terwijl de opvarenden er zich met der woon vestigden.

Volgens de lieden van Mendoe ${ }^{\varsigma}$ en Panagan ${ }^{4}$ ontstond Bangka uit een deel van Tjirebon op Java, dat afyescheiden werd door een zeevorst, met name Manoe ${ }^{\varsigma}$ Malan, wegens een twist met den vorst van Madjapahit, omdat hij de zee wilde droogmaken. Het afgescheiden deel werd Bangka. Voorts was er een Boegineesche vorstenzoon, Sri Gading geheeten, met zijn broeders Sedempoe Awang en Galegoe, die Java en Sumatra rondreisde om een vrouw te zoeken. In China aangekomen, vond hij er eene. Op zijn terugtocht kreeg hij een ongeluk op een rif in de Bangka-zee en de opvarenden kwamen toen op dit eiland en waren de eerste bewoners. De drie vorstenzonen echter keerden naar hun land terug, deden Madjapahit aan en stelden de achtergeblevenen onder de hoede van den vorst van dit rijk.

1 Sri Tri Boeana is de stichter van het Ma Ieische rijk te Singapoera, die van 1160-1208 in Djohor en Malaka regeerde. Sang Soeperba (of volgens anderen Sang Sapoerba) was de vader van dezen en wordt gezegd een afstammeling te zijn van Iskandar Dzoel-Karnein. De bedoelde geslachtslijst is opgenomen in Deel II van het Tijdschr. Batav. Genootschap, blz. 145.

${ }^{2} \mathrm{~B}$ oekit is een onderafdeeling van het district Pangkal-Pinang.

3 In het H. S. كوبق naar de inlandsche uitspraak.

4 Mendoes (Mundo der kaarten, volgens de Engelsche schrijfwijze) is een riviertje en wellicht ook kampong aan de westkust op de grens der districten Muntok, Merawang en Soengei-Selan. Panagan is een onderafdeeling van het district Pangkal-Pinang. 
Volgens de lieden van Balar ${ }^{1}$ ontstond Bangka uit een grooten boom, kajoe bangka, afgedreven uit het land der Boegineezen. Deze werd het eiland Bangka met zijn bewoners.

Volgens de lieden van Pakoe ${ }^{2}$ ontstond Bangka uit het lijk van een zeer groot mensch, dat het eiland Bangka werd en daarnaar zijn naam ontving.

Volgens vele Bangkaneezen stammen de oudste bewoners of van twee broeders, genaamd Akè $\mathrm{Anta}^{\varsigma}$ en Akès Benoe, die van Arabië kwamen. Beiden waren zeer groot, zoodat als zij den eenen voet zetten op Bangka, de andere tot Palembang reikte. Deze namen uit elk land een paar menschen en bevolkten alzoo het eiland.

Volgens de lieden van Bangka-Kota, Permisan ${ }^{3}$ en Penjampar stammen de bewoners van Bangka af van witte vogels; daar er een vorst op Java was, wien een vervloeking trof, zoodat hij en al zijn volk vogels werden, die op Bangka aanlandden. Toen de tijd van die vervloeking om was, werden zij weder menschen. De vorst keerde naar Java terug, maar eenige zijner onderhoorigen bleven op Bangka achter en werden de eerste bewoners.

Volgens de lieden van Poenggoer ${ }^{4}$ kwam een vlot afdrijven van Bantam en strandde op Bangka; de opvarenden gingen aan den wal en waren de eerste bewoners.

$\mathrm{Na}$ de opsomming dezer verschillende legenden zegt de Schr., dat de voorafgaande mededeelingen, die even uiteenloopend als oppervlakkig zijn, tot bewijs strekken van de onkunde der Bangkaneezen, die hunne overleveringen niet konden opschrijven en wisten te verwerken.

Intusschen kan niet ontkend worden, dat hij met veel zorg heeft bjjeengebracht, al datgene, wat door lieden uit verwijderde oorden omtrent den oorsprong van het eiland wordt verhaald; en al mogen dergelijke berichten weinig of geen historische waarde bezitten, ze

1 Balar is een onderafdeeling van het district Soengei-Selan.

Volgens Miquel is op Sumatra van kajoe bangka de wetenschappelijke benaming Ploiarium oblongifolium; op Java daarentegen heet aldus de Rhizophora mucronata (zie Jav. Wdb. i. v. bongka). Ook Saint-Pol de Lias spreekt van een wortelboom, kajoe bangka, aan de uitmonding der rivieren (Chez les Atchés, p. 86).

2 Pakoe is een onderafdeeling van het district Koba.

3 Permisan (of volgens de kaarten Parmisang) is een gebergte, dat zich voor een deel langs straat Bangka uitstrekt en een hoogte van 1325 Rijnl. vt. bereikt. Bangka-Kota is een kampong in het district Soengei-Selan.

4 Poenggoer wordt bij de aanstelling van hoofden door de Bantamsche gezanten hierachter opgegeven als tot het district Muntok te behooren. 
toonen niettemin aan dat er behoefte bestond eene verklaring te vinden voor het onbekende, hoe ongerijmd die dan ook uitviel. Voor zoover ik heb kunnen nagaan, schijnen Europeesche schrijvers met die overleveringen onbekend te wezen.

Alsnu overgaande tot het uiteenzetten zijner eigen meening, vangt hij aan met de verklaring dat hij heeft gezien lontarbladeren en pijagĕm's of koperen platen, waarop met Javaansche karakters in het Arabisch was geschreven, en een piek met pijagĕm van den Sultan van Palembang, en een vredeszwaard van den vorst van Lampong, en een ijzeren kanon afkomstig van Sijantan ${ }^{1}$, en andere teekens, die tot heden bleven bestaan; terwijl hij bovendien heeft gelezen de geslachtslijsten der vorsten van Djohor, Palembang en Java, - een en ander ter opheldering van hetgeen volgt.

De oorsprong van het eiland Bangka is niet met zekerheid op te geven, maar men kan wel zoo wat aannemen, dat Bangka uit een deel van het rijk Djohor is ontstaan, zooals boven werd vermeld. Zonder twijfel is dit echter al lang geleden en dagteekent van den tijd, toen er nog niets op de wereld was ${ }^{2}$. Wat men stellig weet is, dat Bangka vroeger uit een enkelen berg bestond, nl. den berg Maras, die boven de omgeving uitstak; rondom dien berg waren strooken lands, waartusschen men kon varen, ofschoon enkele bij eb droog vielen. Langzamerhand werden deze breeder, leefden er eenige dieren en groeiden daarop allerlei houtgewassen; maar van bewoond zijn was nog geen sprake.

Als eerste bewoners worden genoemd twee lieden van Sumatra, broeder en zuster, die bloedschande gepleegd hadden, zoodat de vrouw zwanger werd. Bevreesd voor opspraak, dreven zij op een vlot af om zich elders te vestigen en kwamen te land aan den voet van evenbedoelden berg. Tusschen de drie toppen maakten zij een woning en ontgonnen het daaromheen gelegen terrein; zij aten de dieren en vruchten, welke er gevonden werden en leefden er rustig voort.

Wat de latere bewoners betreft, zoo luidt het verhaal, dat in

$1 \mathrm{Sij}$ antan is een der Anambas-eilanden aan den ingang der Chineesche zee.

' Duidelijker zou Schr. geweest zijn, als hij had gezegd, dat B. één geheel vormde met het latere rijk Djohor, want, zooals bekend is, werd Djohor in 1511 of 1512 A. D. gesticht door Sultan Mahmoed Sjah van Malaka, die, door de Portugeezen verdreven, naar de rivier van dien naam vluchtte. Van toen af was hier de hoofdplaats en kreeg het rijk den naam van Djohor. 
dien tijd een vorstentelg in het Boegineesche rijk Boni, genaamd Sri Gading, bloedschande wilde plegen met zijn zuster, Dading geheeten; maar dat meisje was hiertoe niet geneigd en gaf er kennis van aan haar vader, met name Toempoe Awang. Deze werd woedend op Sri Gading en joeg hem weg, met last om nimmer weder te keeren, tenzij hij een passende echtgenoote had gevonden. Daarop vertrok Sri Gading met een groot vaartuig en vele menschen en wapenen, ging overal rond langs Celebes, Java, Sumatra en andere Maleische landen en nam op elke plaats, die hij aandeed, met of zonder hun goedvinden veel volk mede, totdat het vaartuig overvuld te Djohor aankwam. Aldaar maakte hij zijn opwachting bij den Sultan, van wien hij een goede vrouw van Chineesche afkomst kreeg. Sri Gading vertoefde langen tijd te Djohor om zijn vaartuig te herstellen. Dit afgeloopen zijnde, wilde hij terugkeeren naar zijn land, maar hij wist den kortsten weg niet, waarom de Sultan hem ten geleide medegaf een Djoeragan van Boegineesche afkomst, genaamd Nachoda Ragam, met vele Djohoreezen. Op zee werden zij overvallen door een hevigen wind en stierf de Nachoda, getroffen door een naald zijner vrouw. Daarna ontstond er oproer en kwamen velen om of werden gewond, zoodat het vaartuig afdreef en strandde tusschen de bergen Maras en Menoembing ${ }^{1}$ en aldaar verongelukte.

De overlevenden gingen aan wal tusschen de drie toppen van den berg Maras. Dáár zag Sri Gading een huis en tuin, de woonplaats der beide lieden van Sumatra, maar die waren reeds dood, gebeten door een slang; hunne lijken waren evenwel nog niet vergaan. Ook alle dieren waren gestorven door gebrek aan voedsel en alleen hun gebeente bleef over. Daar hij twee lijken aantrof, noemde Sri Gading hiernaar het eiland Bangka; en de berg, waar hij de geraamten der dieren vond, kreeg den naam van Boekit Tambon Toelang. Hier bleef hij met zijn volk, etende wat er te eten was, en leed veel gebrek. Daar er maar geen vaartuig kwam opdagen, keerde hij met zijn vrouw en bloedverwanten in een schuitje naar zijn land terug: terwijl de anderen achterbleven, onder belofte, dat hij hen zou laten halen. Sri Gading ging ò terug naar Makassar, ò wel naar Java, óf kreeg misschien een ongeluk op zee, want er verscheen niemand van zijnentwege om de achtergeblevenen te halen. Van deze stierven enkelen en anderen kregen kinderen. $\mathrm{Na}$ verloop van tijd namen zij in aantal toe, maar leefden door onkunde,

1 Menoembing is een berg nabij de hoofdplaats en heeft een hoogte van 1560 R. vt. 
luiheid en onreinheid als dieren en kleedden zich met boomschors en bladeren. Honderden jaren bleven zij in dien toestand. Het land werd droger en daardoor grooter; van allerlei volkstammen vestigden er zich menschen en van daar dat op Bangka zelfs geen oorspronkelijke taal is bewaard gebleven. ${ }^{1}$

In dezen toestand van verwildering landde het vaartuig van een Arabier, met name Soleman, bij den berg Menoembing en vervolgens tusschen de drie toppen van den berg Maras. Hij zag de genoemde lieden in kommer en onwetendheid leven en dat velen ziek waren, zonder met geneesmiddelen bekend te zijn. Daarom liet hij mengkoeboeng-bladeren ${ }^{2}$ kneden, vermengd met pisang, tot er een sap uitkwam, waarmede hij hen het hoofd liet inwrijven en velen herstelden. Ook onderrichtte hij hen in den godsdienst en leerde hen voor hun levensonderhoud zorgen. Er waren er die hem volgden, maar anderen wilden niet uit luiheid of onkunde. Toen verzon Soleman er iets op. Hij deed onderzoek naar hun afkomst en vond een afstammeling van den meer vermelden gezagvoerder van het gestrande vaartuig. Dit achterkleinkind nam hij als zoon aan en gaf hem den naam van Si Banoer. Hij onderwees hem van alles en stelde hem later tot hoofd aan, als hoedanig de lieden hem gaarne gehoorzaamden. Daarop ging Soleman naar Java en gaf het eiland Bangka met zijn bewoners over aan den vorst van Madjapahit, die met Soleman derwaarts zond een mantri, genaamd Patah Gadjah Mada. ${ }^{3}$ Zij gingen eerst naar den berg Manoembing en naar een vlakte aan den voet, alwaar zij den tronk van een boom vonden, waarom zij die plaats Boengoer heetten en aldaar hoofden aanstelden. Vervolgens gingen zij naar Maras en omdat de lieden bij hunne komst vlaggetjes geplaatst hadden, noemden zij die streek Pandji

$1 \mathrm{H}$. M. LANGE bestrijdt op blz. 11 van zijn reeds angehaald werk het gevoelen van hen, die vermeenen dat Bangka vroeger met Sumatra vereenigd zou geweest zijn, en wel wegens den alluvialen bodem van Sumatra's oostkust, welke door aanslibbing voortdurend toeneemt. Hij is van oordeel, dat straat Bangka eeuwen geleden veel breeder was en dat de eilanden Bangka en Lingga, als een voortzetting van de eilandenreeks van af het schiereiland Malaka, toenmaals verder van de kust waren verwijderd. Volgens CROockewIT en Dr. EPP is graniet het hoofdbestanddeel van den bodem.

${ }^{2}$ In geen enkel woordenboek komt dit woord voor; ook niet bij Miquel of Filet.

3 Deze en de volgende overlevering wettigen het vermoeden, door prof. VETH in noot 5 op blz. 194 van het Tijd schr. v. N. I., ja arg. 1850 uitgesproken, dat de Javaansche Koloniën op Bangka afkomstig zijn van het machtige rijk van Modjopait, dat door verovering en kolonisatie naar de oppermacht in den geheelen Archipel streefde. 
en lieten er $\mathrm{Si}$ Banoer als hoofd achter. De vlakte daarnevens noemden zij Djeroek, naar een boom, en bepaalden van elk deel de grenzen en de wijze, waarop het bestuurd moest worden; welke bijzonderheden op een pijagĕm in het Arabisch met Javaansche karakters worden uiteengezet. Dit afgeloopen zijnde, keerden zij naar Java terug en Bangka nam voortdurend in zielental toe; en vele bergen en plaatsen kregen namen, naar menschen, naar dieren, naar boomen, naar visschen, naar riviertjes, naar eigenaardigheden.

Zeer lang daarna droeg een andere vorst van Madjapahit aan zekeren Pangeran Toemenggoeng Binata op, te onderzoeken hoe het met Bangka stond, omdat daarvan gedurende geruimen tijd niets was gebleken. Deze ging eerst naar de rivier Bentilan en van daar over land naar Mendoe ${ }^{\varsigma}$ en Djeroek. Op de eerste plaats stelde hij een hoofd aan, met name Patih Tali, en op de tweede Patih Pandjang Djiwa en maakte andere hoofden aan hen ondergeschikt. Hij regelde bovendien het bestuur en deed onderzoek naar de voortbrengselen. Maar Bangka leverde toen niets op; de bewoners aten nog uit pisangbloemscheeden; hun kleeding bestond uit boomschors met een hoofdbedekking van palmbladeren en zij maakten gebruik van blaasroeren '; zij bewerkten ladang's en vlochten matten en wat ze krïgen konden.

Bij zijn terugkeer naar Java gaf hij het bewind over aan de twee genoemde Patih's. Deze stierven na verloop van tijd en werden door anderen opgevolgd; en later ontstonden er veel Patih's op Bangka, door hunne onderhoorigen tot dien rang verheven, daar er niemand meer van Java kwam. Zoo werd te Djeroek tot Patih aangesteld Reksa Koening en tot Hoeloebalang of legerhoofd Selangoer; de Patih te Mendoe ${ }^{\varsigma}$ heette Ngintjar, die te Depak Patih Kembar, die te Tjempoerak ${ }^{2}$ Patih Ngabehi; terwijl de Patih Singa Pandjang Djongor een versterkte plaats bouwde aan de monding der rivier $M_{e n d o e^{\varsigma}}$, welke hij Kapoer noemde. Deze wilde alleen met zijn eigen stam, de Boegineezen, omgaan. In het geheel waren er dus vijf Patih's op Bangka met aan hen ondergeschikte hoofden.

${ }^{1}$ In weerwil van de stellige verklaring op blz. 173 van Band V van het Internationales Archiv für Ethnographie, dat blaasroer in het Maleisch soempitan heet, zien we hier in het H. S. van Hadji Idris, die als specialiteit in die taal mag genoemd worden, daarvoor wel degelijk

${ }^{2}$ Elders komt voor Djempoerak, als onderafdeeling van het district SoengeiLijat; de ware schrijfwijze is onzeker. 
In dien tijd werd Bangka overvallen door een volk, genaamd Meloekoet, van Sumatra of de Batak-landen afkomstig, daar zij menschen aten, onder aanvoering van hun vorst, Radja Tidoeng, die de Bangkaneezen versloeg, zoodat velen omkwamen, ook de Patih's van Meudoe ${ }^{\varsigma}$ en Djempoerak. Alleen de Patih van Depak hield het zoo goed mogelijk in zijn kampong uit. Evenzoo de Patih van Djeroek, wiens kampong echter verwoest werd; maar hij met zijn Hoeloebalang Selangoer en zijn volk hielden zich schuil in de bosschen en verbleven daar langen tijd genoegzaam zonder eten, daar niemand hen te hulp kwam. Vele Bangkaneezen stierven, enkelen opgegeten door den vijand, anderen door hongersnood.

Toenmaals ging er een Arabisch vaartuig voorbij onder Toean Sjarah. Deze hoorde van de ramp maar was te zwak om te helpen, waarom hij hulp ging vragen te Djohor. De Sultan van Djohor was hiertoe gaarne bereid en verbond zich met den Sultan van Menangkabau om de Meloekoet te tuchtigen. De eerste gaf een vloot, de twee landsoldaten onder aanvoering van Radja Alam Harimau Garang, en aan Sjarah werd het opperbevel over allen toevertrouwd. De zeesoldaten moesten het vaarwater rondom Bangka bewaken, de landmilitie ging bij de rivier Djeroek aan wal.

Toen de Bangkaneezen hen zagen, kwamen ze allen aan boord der vaartuigen uit vrees voor de Meloekoet.

Gevraagd naar hunne hoofden, wezen zij als zoodanig aan Patih Reksa Koening met zijn Hoeloebalang Selangoer. Aan dezen werd opgedragen twee versterkingen te bouwen, waar de Bangkaneezen bescherming konden vinden, een voor Sjarah, genaamd BangkaKota, en een voor Radja Alam van waringin-hout, en daarom KotaBeringin geheeten '. In dien tusschentijd werden de Meloekoet geslagen en velen kwamen om. Willende ontvluchten werden zij door de vaartuigen op zee tegengehouden en moesten dus terug-, keeren.

Radja Tidoeng ging met een deel van zijn volk naar den heuvel Semoegiri en anderen verborgen zich in holen, die zij in den grond groeven, nabij Tjengal, waar zij zonder levensmiddelen verbleven.

Omsingeld door Sjarah en Radja Alam werden allen gedood.

De Bangkaneezen onderwierpen zich toen aan deze beide aanvoerders, behalve Patih Pandjang Djongor te Kota-Kapoer aan de rivier Mendoes. Deze werd nu verdacht de Meloekoet te hebben

1 Beide plaatsen zijn gelegen aan de westkust in straat Bangka. 
aangezet tot den inval in Bangka; vooreerst omdat hij geen hulp verleende, en ten tweede omdat zijn verblijfplaats niet verwoest was en hij weigerde zijn opwachting te komen maken. Er werd besloten hem te tuchtigen en een deel van het leger trok op naar zijn kota. Deu avond vóór de aankomst der troepen ging een zijner zes dochters, met name Doepang, naar buiten om rijst te stampen en stierf dadelijk, gebeten door een slang. Een zuster, die haar wilde helpen, schrikte op het zien van haar lijk en dacht, dat zij door de soldaten was gedood. Op haar geschreeuw kwam haar vader toeschieten en was zeer ontsteld; daar hij meende, dat zijn troepen naar den vijand waren overgeloopen, vluchtte hij in het bosch. Toen ontstond er verwarring en velen werden gedood. Den volgenden morgen kwamen Sjarah en Radja Alam en de overgeblevenen gaven de kota aan hen over en de vijf achtergelaten dochters van den Patih werden uitgehuwelijkt aan de Perwatin's of hoofden, die mede ten strijde waren getogen. Patih Pandjang Djongor kwam van honger in het bosch om. $\mathrm{Nu}$ regelden beide aanvoerders alles: Sjarah werd Radja van Bangka-Kota en Radja Alam van Kota-Beringin; zij voerden den islam in en Bangka werd een onderhoorigheid van Djohor met gemengde Javaansche en Maleische gebruiken. De helft van het leger ging terug naar Djohor en Menangkabau; de anderen bleven achter onder vrijstelling van dienstplichtigheid, behoudens het verleenen van hulp ingeval van oorlog of opstand. Zij stelden ook hoofden onder de Patih's aan, met den titel van Batin ', naar dien der hoofden van de zeelieden der Lingga-stammen; en zij die van Djohor afkomstig waren en op Bangka achterbleven, werden de Seka's en trekken Bangka en Billiton rond tot op heden.

Zoolang Bangka onder Djohor stond, leefden de bewoners in vrede en voorzagen in hun levensonderhoud door het planten van

1 Volgens het Mal. Woordb. van Von De Wall is batin een titel van gewestelijke hoofden in het voormalige rijk Djohor (thans Lingga en Singapoera), staande onder den Orang-Kaja en boven de Pengoeloe's, waarvan zij gewoonlijk eenigen onder zich hadden; perwatin of proatin is daarvan afgeleid. VAN DER TuUK zegt, dat batin in het Lampongsch $r i j k$ beteekent en dus met Orang-Kaja gelijk staat, en dat proatin of parawatin door de rijken moet verklaard worden (B a t. Woor b. i. v. mora).

Dat er ook nu nog betrekking bestaat tusschen de genoemde eilanden, blijkt uit de Beschrijving van den Riouw-Archipel door E. Netscher in het Tijdschr. Batav. Genootschap, D1. XII, die opgeeft, dat in de kampongs Terentang, Lalang en Sepintjan van Lingga vele uitgeweken Bangkaneezen wonen; terwijl hierachter onder het jaar $1216 \mathrm{~A}$. H. of $1801 \mathrm{~A}$. D. van een verhuizing naar Singkep sprake is. 
padie op ladang's, zooals dit de gewoonte is bij andere volken. Van Sjarah wordt het graf te Bangka-Kota ${ }^{1}$ tot heden als een heilige plaats vereerd.

Onder Radja Alam Harimau Garang werd het bestuur uitgeoefend door Patih Reksa Koening en zijn Hoeloebalang Selangoer; maar Bangka leverde toen nog geen voordeel op, waarom de Sultan van Djohor het afstond aan den vorst van Menangkabau.

Tijdens het oppergezag van dezen had er een uitbarsting plaats van den berg Maras, waardoor vele dorpen verwoest werden en tal van menschen omkwamen. Bij die gelegenheid vonden enkele personen steenen, die gesmolten en weer vast geworden waren. Niet wetende hoe dit kwam, vertoonden zij die verharde klompen aan Radja Alam en deze wist, dat zij uit ijzer bestonden, zoodat hij Patih Reksa Koening en de andere Perwatin's opdroeg meerdere van die steenen te laten opgraven. $\mathrm{Nu}$ hadden menschen van Pakoe bij het branden hunner ladang's eveneens gesmolten steenen gezien en daarom werd gelast hier eerst te gaan graven en vonden zij steenen, die bij verhitting in ijzer veranderden ${ }^{2}$.

Radja Alam woonde voortdurend te Kota-Beringin; na zijn dood werd zijn graf als een heilige plaats vereerd, dat ook het geval is met een stuk van de kiel van het vaartuig dat hem overbracht, tot nu toe zichtbaar in de daarlangs stroomende rivier. Kort na hem stierven Patih Reksa Koening en zijn Hoeloebalang Selangoer, maar de vorst van Menangkabau wilde geen ander hoofd zenden, omdat Bangka niets opleverde. Van daar dat er geen algemeen hoofd meer was en alleen de Batin's overbleven. Hierdoor verwilderden de Bangkaneezen; zij hielden zich op in de bosschen en bouwden geen woningen meer, ook al uit vrees voor de zeeroovers. Slechts te Bangka-Kota en Kota-Beringin bleven eenige Maleiers gevestigd.

In dien tijd kwamen zeeroovers van Lampong en deden Pandji aan, alwaar zij den Batin $\mathrm{Pa}^{c}$ Mangil uitnoodigden tot een hanengevecht aan Kaap Roe ${ }^{3}$. Hij was de verliezende partij en hierover zoo ontstemd, dat hij zijn onderhoorigen verzamelde om het verlorene

$1 \mathrm{~B}$ a n g ka-Kota is de oude hoofdplaats van het tegenwoordige mijndistrict Soengei-Selan, sedert naar het noorden tegenover de Nangka-eilanden verplaatst.

2 De aanwezigheid van ijzererts te Pakoe is door latere geologische onderzoekingen bevestigd.

${ }^{3} \mathrm{Pandji}$ is een onderafdeeling van het district Belinjoe en $\mathrm{Tandj}$ oe ng Ro e en kaap in de Klabat-baai. 
te herwinnen. Bij dien strijd kwamen vele Lampongers om en anderen vluchtten naar hunne prauwen en keerden naar hun land terug, om hun vorst of opperhoofd kennis te geven van hetgeen hun was overkomen. Deze kwam met vele vaartuigen op Bangka aan en verwoestte de geheele streek van Pandji tot Maras. De overgebleven Bangkaneezen verborgen zich in de bosschen, zoo ook $\mathrm{Pa}^{\varsigma}$ Mangil. Het hoofd van Maras, genaamd Tjermin Djati Soeala vluchtte naar Bakoeng ${ }^{1}$ met drie Batin's en al zijn volk en vroeg hulp aan Batin Tijang van Pelawan.

Toen boden zij den Lampongers weerstand, maar door onkunde van hun aanvoerder, $\mathrm{Ma}^{5}$ Mentoeh, in het oorlogvoeren werden vele Bangkaneezen gedood. Door de Maleiers van Kota-Beringin geholpen kwam er een einde aan den strijd en sloten de vorst van Lampong en Tjermin Djati Soeara vrede, als teeken waarvan zij hun zwaard en kris ruilden ${ }^{2}$. De eerste ging naar zijn land terug, medenemende wat hij vroeger had buit gemaakt. Ten gevolge hiervan hielden de Bangkaneezen zich schuil in het binnenland en ook Tjermin Djati Soeara ging niet weder naar Maras. Dit duurde honderden jaren voort, de bewoners namen in aantal toe, maar verbleven in de bosschen, etende wat er maar te krijgen was en niets afwetende van een opperhoofd of van vroegere onderwerping aau Java, Djohor en Menangkabau.

Op zekeren tijd nu zeilde een vaartuig van Bantam ${ }^{3}$ en deed Bangka aan, om aldaar het ontbrekende voor de reis aan te vullen. De opvarenden ontmoetten eenige lieden aan het strand van Soekal ${ }^{4}$ en hoorden van hen, wat er alzoo in den loop van jaren was voorgevallen. Teruggekeerd deelden zij hunne bevinding mede aan den Sultan van Bantam, die een onderzoek instelde waaruit bleek, dat Bangka vroeger had behoord tot Madjapahit. Hij benoemde daarop Pangeran Panembahan Sarpoe en Boepati Noesantara tot Radja's over dat eiland. Deze togen op weg en landden te Soekal van waar zij over land verder trokken zonder iemand tegen te komen. In een bosch voetstappen van menschen ontdekkende, bleven zij daar stil.

$1 \mathrm{~B}$ a koeng is nog heden een tinmijn in het district Pangkal-Pinang. Later wordt dat hoofd $\mathrm{Tj}$. Dj. Soeara geheeten.

2 Dit is het vredeszwaard, waarvan boven sprake is.

s Het H. S. heeft natuurlijk بنت = B a nt èn.

4 Vermoedelijk is Soe kal een juistere schrijfwijze van het op de kaarten voorkomende Soeka, als een riviertje, dat nabij Tandjoeng Poenei in straat Bangka uitmondt. 
Niet wetende waar van daan water te krijgen, lieten zij een put graven en deze plaats draagt nog altijd den naam van Telaga Soekal.

Den volgenden dag kwamen zij lieden tegen, die naar het strand wilden gaan en vroegen naar den weg en werden overal rondgeleid van de eene plaats naar de andere. Zij gaven daarbij kennis van hun benoeming en kozen Bangkaneezen tot Patih en Batin, om onder hen het volk te besturen, en wel:

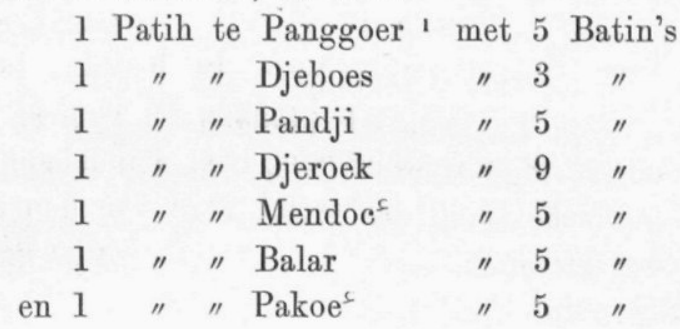

Iedere Patih kreeg een pijagĕm, behalve de Patih's van Panggoer, Pandji en Djeroek, omdat deze er nog een hadden van Soleman, en elks gebied werd behoorlijk omschreven.

Ook werden oude gebruiken, sedert door Javaanschen, Boegineeschen en Maleischen invloed verbasterd, op nieuw vastgesteld, en waren de afstammelingen van Maleiers alleen tot het presteeren van dienst in geval van oorlog verplicht.

Daarop keerde de Panembahan terug naar Java en bestuurde Boepati Noesantara alleen het eiland. De bewoners leefden in vrede en brachten hem als schatting matten, kalk en pisangbladscheeden op; terwijl hij te Bangka-Kota woonde en die producten naar Bantam zond. Wegens de geringe waarde gaf de Sultan er echter niet veel om.

Intusschen regeerde te Palembang Sultan Abdoe'r-rachman ${ }^{2}$, die den Pangeran Adi gelastte naar Bantam te gaan, om de dochter van den Sultan aldaar ten huwelijk te vragen. Nadat partijen hieromtrent waren overeengekomen, ging de Pangeran de bruid halen, met vele vaartuigen beladen met kostbaarheden, naar het gebruik onder vorsten medebrengt. Ter reede van Bantam aangekomen, ontstond er twist tusschen zijn gevolg en de opvarenden van prauwen van den Sultan, waarom den gezant verboden werd aan wal te komen. Deze, hierdoor beleedigd, bemachtigde twee vaartuigen van den

${ }^{1}$ In het H. S. is hierbij ter verduidelijking "Mentoc" gevoegd; vgl. de aanteekening 4 op blz. 7 , waar echter van $\mathrm{Poeng} g$ o e r sprake is.

${ }^{2}$ Deze is meer bekend als Abdoe'r-rachman Tjindi Balang en regeerde van 1651-1696. 
Sultan en bracht ze naar Palembang, met het bericht hoe de oneenigheden waren ontstaan. De Sultan van Bantam was zeer vertoornd en zond zijn zoon Ratoe Bagoes met troepen om Palembang te tuchtigen. Gedurende drie maanden werd dit land afgeloopen en was zijn ondergang nabij, toen er plotseling hulp kwam opdagen van de vorstentelgen, die als kluizenaars leefden op den heuvel Segoentang '.

Ratoe Bagoes moest daarop in allerijl terugtrekken en deed Bangka aan. Toen Boepati Noesantara dit hoorde, liet hij hem allerlei vruchten en levensmiddelen brengen en voorzag hem en de zijnen van het noodige. Zij dachten er over Palembang op nieuw aan te vallen, waartoe hulp gevraagd werd van den Sultan van Bantam. Hierop kwam evenwel geen antwoord, totdat Ratoe Bagoes te Bangka-Kota stierf, alwaar zijn graf nog altijd in eere wordt gehouden.

$\mathrm{Na}$ de vorige gebeurtenissen verliepen er dertien jaren. De Sultan van Bantam stierf en werd vervangen door zijn zoon, maar over Palembang regeerde nog dezelfde Sultan. De laatste hoorde, dat Boepati Noesantara een zeer schoone dochter had; hij zocht vriendschap met hem aan te knoopen en zond verscheidene prauwen met een gezant naar Bangka-Kota om haar ten huwelijk te vragen. De Boepati vroeg uitstel om eerst de goedkeuring van den Sultan van Bantam te vragen, maar de Sultan van Palembang vreesde dat deze er niet in zou toestemmen en zond dus andermaal een gezant om Boepati Noesantara uit te noodigen te Palembang te komen, ten einde de zaak met hem in persoon te bespreken. Boepati Noesantara was wel bevreesd voor moeilijkheden als hij niet ging, maar durfde toch niet, daar hij vroeger aan Ratoe Bagoes beloofd had nooit naar Palembang te zullen gaan of water uit de rivier van Palem-

${ }^{1}$ Bij de legende der lieden van Njaloe (zie boven blz. 117) wordt deze heuvel ook genoemd. Evenzoo in het Maleische werk Sfoe 1 a 1 et oe assal at hina, waar het heet, dat dáár drie afstammelingen van Dzoelkarnein woonden. Volgens VAN Sevenhoven (Verhand. B a t a v. G e noots chap, D e e 1 IX, bl z. 60) ligt een uur boven de hoofdplaats Palembang een heuvel, B o ekit Seboen. $\mathrm{t}$ a $\mathrm{ng}$, waarvan de overlevering zegt, dat dit het eerste land was uit zee te zien en dat naderhand het tegenwoordige land tot den mond der rivier is aangespoeld; ook bevindt zich aldaar het graf van Radja Iskandar en wordt er in bijzondere gevallen een eed afgelegd. Zeer waarschijnlijk is dit dezelfde heuvel, als in het H. S. wordt vermeld; te meer daar V VN DER TUUK Seboentang voor de Palembangsche uitspraak van Sigoentang opgeeft (Les Manuscrits Lampongs, p. XIV), ofschoon dezelfde geleerde in het $\mathrm{T}$ ij ds chr. Ne d. In die 1849 , I, blz. 386 , van S a g o e n t a ng spreekt.

6e Volgr. I. 
bang te drinken. Toen de Sultan dit hoorde, liet hij eene plaats zoeken aan de kust, tegenover Bangka-Kota, waar het water der rivier niet langs stroomde. Men wees als zoodanig aan Soengei Pasoegin en in het jaar 1082 (1671 A. D.) ging de Sultan derwaarts met zijn staatsdienaars, krijgsoversten en troepen, allen behoorlijk gewapend. $\mathrm{Nu}$ liet hij Boepati Noesantara verzoeken aldaar te komen, als zijnde die plaats niet begrepen in de belofte aan Ratoe Bagoes. Bang zijnde voor oneenigheden, maakte de Boepati zich gereed er heen te vertrekken, toen er antwoord kwam van Bantam en de Sultan van dit rijk hem toestond naar goedvinden te handelen, maar tevens in overweging gaf in het huwelijk toe te stemmen, daar Palembang dicht bij Bangka was gelegen en, ingeval van oorlog, Bantam moeilijk kon helpen, daar het zoo ver verwijderd was en ook geen voordeel van Bangka had. Om die reden gaf de Sultan van Bantam het eiland over aan Boepati Noesantara, terwijl hij er zich geheel aan onttrok.

Zeer verheugd over deze beslissing ging de Boepati dadelijk naar Pasoegin, zijn dochter medenemende, die hij aan den Sultan van Palembang ten huwelijk gaf. Sedert bestond er tusschen die beide hoofden een zeer vriendschappelijke verhouding. Met den dood van Boepati Noesantara erfde de vrouw van den Sultan het eiland Bangka en aldus kwam het onder Palembang en werden de Patih's en Batin's aan den Sultan ondergeschikt, ofschoon overigens in de regeling van het bestuur geen verandering $\mathrm{kwam}^{{ }^{1}}$.

De Maleiers, die te Muntok wonen, worden gezegd af te stammen van een Maleier, genaamd Wan Awang ${ }^{2}$, een zoon van Datoe Engkoe of Intje ${ }^{\varsigma}$ Engkoe, die een afstammeling was van een Maleischen Mantri uit Trengganau. Deze Oewan Awang was gehuwd en had kinderen te Trengganau, Kelantan, Patani, Kambodja ${ }^{3}$ en op het eiland Sijantan. Zijn vrouw te Sijantan was een dochter

1 Deze lezing verschilt eenigszins van die, welke gevonden wordt bij DE Sturlez, o. c. blz. 6 , waar het heet, dat een weduwe van den vorst van Bangka huwde met den Sultan van Palembang, die daardoor in het oppermachtig bezit van dit eiland kwam.

Zonder verdere bijzonderheden te vermelden, noemt Horsfield Boepati Noesantara den laatsten vertegenwoordiger van den Javaanschen souverein ( $\mathrm{T}$ ij d sch r. v. N. Indie, ja a rg. 1850 D e el I, blz. 197).

${ }^{2} \mathrm{~W}$ an of $\mathrm{Oew}$ an is een verkorting van $\mathrm{t}$ o e w a $\mathrm{n}=$ het Maleische Intje $\mathrm{e}^{\varsigma}$.

3 Dit zijn Maleische staatjes op het schiereiland Malaka, waarvan verschillende bijzonderheden voorkomen in de "zeereis van Abdoellah be n "Abdoelkadir Moensji van Singapoera naar Kalantan", in 1855 door prof. PiJNAPPEL te Leiden uitgegeven. 
van het opperhoofd, den Datoe ${ }^{5}$ Pangeran '. Hij kreeg bij haar drie zoons, Oewan Akoeb, Oewan Sabar en Oewan Sirin. Zij had ook nog een broeder, met name Ibrahim, een zoon van den Datoe Pangeran en een chineesche vrouw; maar deze vrouw werd door den Datoe ${ }^{\varsigma}$ Pangeran weder afgestaan aan haar eersten man Abdoel Hijat en kreeg bij hem meerdere kinderen, nl. Abdoel Djabar, Abdoel Chalik, Zain Alabadin, Abdoel Gani en Ismael. Abdoel Djabar kreeg zes kinderen; vijf er van werden uitgehuwelijkt en alleen de jongste, genaamd Zamnah Timangan Intje Ajoe, bleef over.

Intusschen waren er te Palembang twee Sultans, één genaamd Sultan Anom Ratoe Kamaroe'd-din en één genaamd Sultan Palembang-Lama ${ }^{2}$, die niet in goede verstandhouding leefden.

Een broeder van den eersten, Ratoe Mahmoed Badroe'd-din, kon het met geen van beiden vinden en vertrok daarom met achttien prauwen en de dienaren, die hem genegen waren, om hulp te zoeken en een aanval tegen Palembang te ondernemen, met het doel zelf Sultan te worden.

Hij ging eerst naar Belinjoe en vertoefde een maand te Pandji; vervolgens trok hij naar Djohor, waar hij zich aan den Sultan onderwierp, die hem ontving en broederlijke vriendschap bewees. Hulp tegen zijn broeder kon hij echter niet krijgen; wel wilde de Sultan helpen om Ratoe Mahmoed in een der onderhoorigheden van Djohor of in een ander rijk tot vorst te verheffen. Hiervan kwam dus niets, maar door zijn vriendschappelijke verhouding tot den Sultan kreeg Ratoe Mahmoed grooten invloed, zoodat de andere Radja's en staatsdienaren hem benijdden en verzochten, dat hij uit Djohor zou verwijderd worden.

De Sultan weigerde zulks en wenschte te wachten, tot hij er zelf om vroeg; maar gaf toch bij een vernieuwd aandringen aan hun verlangen gehoor onder drie voorwaarden: $1^{\circ}$ dat na de mededeeling van het besluit aau Ratoe Mahmoed zijn vaartuigen niet langer te Djohor mochten blijven; $2^{\circ}$ dat bij een aanval zijnerzijds slechts in geval van groote verliezen weêrstand mocht ge-

1 In de Maleische landen is dat o e" of da to" de titel voor opperhoofden en hooge ambtenaren en pangéran, oorspronkelijk een Javaansche titel voor vorstelijke en voorname personen. Volgens VON DE WALL voert een der hoofden van het eiland Sijantan dien titel als zijnde van Broeneische afkomst.

2 Deze is de in de Palembangsche kronijken voorkomende Sultan Mohamed Mansoer Kebon Gede, die nog vóór zijn dood afstand deed van den troon ten behoeve van zijn zoon, welke den naam aannam van Sultan Anom, den lateren schoonvader van Sultan Mahmoed Badroe'd-din. 


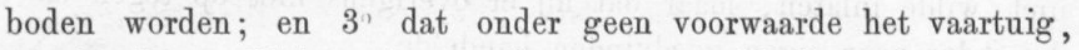
waarin Ratoe Mahmoed en zijn vrouwen zich bevonden, mocht worden beschoten of aangevallen.

Ratoe Mahmoed, ofschoon ontsteld door het onverwachte bevel, daar hij zich geenerlei schuld bewust was, volgde het op In zee gekomen en ziende, dat vele toebereidselen gemaakt waren om hem zoo noodig met geweld tot heengaan te dwingen, werd hij woedend en gelastte zijn volk te schieten, maar van den kant van Djohor werd dit niet beantwoord. Eerst na een heftigen aanval verdedigden zich de Djohoreezen, maar lieten het vaartuig van Ratoe Mahmoed ongedeerd. Hierover verbaasd, begreep hij dat zijn verwijdering geschiedde zonder instemming van den Sultan. Daarom liet hij met schieten ophouden en zeilde verder tot hij aankwam op het eiland Sijantan.

Wan Akoeb, zoon van Wan Awang, was toen hoofd te Sijantan. Deze nam Ratoe Mahmoed met zijn volgelingen op en wees hun een plaats aan, waar zij konden verblijven. Al spoedig kwam hem ter oore, dat er in de kampong van Wan Akoeb een schoone vrouw was, met name Zamnah, de dochter van Abdoel Djabar. Haar vader was echter niet aanwezig, maar op bedevaart naar Mekka, zoodat Wan Akoeb als haar voogd optrad. Aan deze vroeg hij haar ten huwelijk en, hoezeer die er niet op tegen had, wilde hij toch eerst de toestemming van den Sultan van Djohor vragen. Van die zijde werd op de meest welwillende wijze de gevraagde vergunning verleend.

Op den avond, dat het huwelijk zou plaats hebben, kwam de vader der bruid, Abdoel Djabar, met zeven menschen op een vlot van het eiland Lengkawi ' , waar zijn schip was vergaan, te Sijantan aan. Hij voltrok zelf het huwelijk en veranderde den naam zijner dochter in Mas Ajoe en zijn eigen naam in-Meratoe Dalam, door zijn nageslacht gewijzigd tot Datoe ${ }^{5}$ Dalam.

Van zijn verblijf te Sijantan maakte Ratoe Mahmoed gebruik om Wan Akoeb over te halen hem hulp te verleenen tegen Palembang, onder belofte bij goeden uitslag een deel van Bangka af te staan. Deze was daartoe zeer geneigd en haalde eenige Maleiers van Boegineesche afkomst onder Dajang Berani over hem daarbij te helpen, zoo de Sultan van Djohor het namelijk toestond. Op een derwaarts gezonden brief kwam als antwoord, dat de Sultan zich met de zaak

$1 \mathrm{Lengkawi}$ is wellicht hetzelfde als het op kaarten voorkomende eiland Leng k o w a s, benoorden Billiton. 
niet wilde inlaten, maar dat hij er overigens niet op tegeri had, dat ieder naar eigen goedvinden handelde.

Hierop vertrok Ratoe Mahınoed in het jaar 1127 (1715 A. D.) met zijn vrouw en al de bovengenoemde afstammelingen van $\mathrm{W}$ an Awang, Datoe 5 Dalam en zijn vijf dochters uitgezonderd, vergezeld van de gewapende troepen onder Dajang Berani.

Hij ging eerst naar Bangka-Kota, waar hij de rivier opvoer, terwijl de troepen van Dajang Berani op de Nangka-eilanden bleven.

Vervolgens zond hij in het geheim bericht aan de vorstentelgen van Palembang-Lama, die het al vroeger met hem eens waren, dat hij zich aldaar bevond. Voor Sultan Ratoe Kamarroe'd-din was hij echter bang, daar deze zich na zijn vertrek behoorlijk had toegerust en zelfs versterkingen en wachthuizen had laten bouwen tot aan Soengsang. ' ${ }^{1}$ Terwijl Ratoe Mahmoed zich te Bangka-Kota bevond, waren de vaartuigen, die Wan Akoeb met zijn broeders Wan Sirin en Wan Sabar overvoerden, afgedreven en de rivier Oelim binnengeloopen. ${ }^{2}$ Daar zagen zij veel sijamang's ${ }^{3}$, waarom zij vermoeden, dat er tin zou wezen, om reden zij de bewerking van dit metaal door de Maleiers en Chineezen te Djohor gezien hadden. Zij gingen aan het graven aan de oevers dier rivier, vonden er veel tin en namen een stuk als monster mede. ${ }^{4}$ Toen Ratoe Mahmoed dit bericht vernam, was hij zeer verheugd en droeg aan de hoofden op om het geheele eiland Bangka te doorkruisen en een onderzoek te doen naar de aanwezigheid van tinerts, dat zij op vele plaatsen aantroffen.

Hij verbleef nu drie maanden op Bangka, zich voortdurend versterkende. Op zekeren nacht makte zijn vrouw hem wakker, zeggende, dat hij dadelijk moest optrekken als hij vorst wilde

1 Aldus heet de plaats, waar de Moesi zich in straat Bangka in zee stort.

${ }^{2} \mathrm{O}$ e $1 \mathrm{im}$ is een rivier in het district Toboali, die in straat Bangka uitmondt.

$3 \mathrm{Sij}$ a mang is een soort van langarmigen aap, Hylobates syndactilus. Het verband tusschen het voorkomen dezer aapsoort en de aanwezigheid van tinerts is niet recht duidelijk, tenzij er mede bedoeld wordt, dat men die ook in Djohor vindt.

4 In het $\mathrm{T}$ ij d s c h r. v. Ne d. In di e, ja a rg. 1846 , is hierover een andere lezing en zouden de eerste tinmijnen bewerkt zijn in het district Merawang, en wel ten gevolge der ontdekking van de erts, welke door Batin Angor in 1709 in Depak tot metaal gesmolten werd bij het verbranden eener ladang, waarbij een gedeelte erts bloot kwam. Tevens wordt vermeld, dat dezelfde ontdekking bijna gelijktijdig geschiedde te Tjimporak (D je m poerak of $\mathrm{Tj}$ e m poe rak, zie boven), bij de rivier Mabat, uit welke men tinzand haalde. 
worden over het geheele Palembangsche rijk, daar zij gedroomd had, dat zij Palembang inslikte. Ziende dat hij haar niet wilde gelooven, zeide zij, dat hij haar hoofd zou schudden, hetwelk hij deed en waarbij een geluid werd gehoord als van het water in een kokosnoot. Hierover verbaasd, geloofde hij alles wat zijn vrouw hem verteld had. Beiden stonden op en zij nam een mes mede, een erfstuk van haar vader, dat gezegd werd geluk aan te brengen. Hij liet nu dadelijk alles voor het vertrek gereed maken en zeilde naar de Nangka-eilanden, terwijl Wan Akoeb en zijn broeders te Bangka achterbleven, om toezicht te houden over de bewerking van het tin. Daar de troepen van Dajang Berani nog niet klaar waren, gelastte hij dat die zouden volgen en zeilde hij alleen naar Soengsang. Hier willende binnen varen, werd hem zulks verboden door den Mantri, die dáár de wacht hield en die eenige schoten deed lossen, welke Ratoe Machmoed evenwel niet beantwoordde. Hij ging met zijn vrouw boven op de kajuit zitten en dit ziende, dacht de Mantri, dat Ratoe Machmoed niet kwam om Palembang te beoorloogen, daar hij maar één vaartuig bij zich had. Het schieten hield toen op en hij werd doorgelaten, ofschoon vergezeld van de Mantri's en Hoeloebalang's, die te Soengsang en in andere versterkte plaatsen gelegerd waren; zoodat hij met een groot gevolg ter hoofdplaats aankwam, waar zijn vrienden niet weinig verwonderd waren, dat hij zoo ongedeerd tot Palembang had kunnen doordringen; terwijl zijn troepen, door niemand tegengehouden, eveneens de rivier waren opgevaren. Om kort te zijn het duurde hierna niet lang of Sultan Ratoe Kamaroe'd-din moest wijken voor Sultan Ratoe Badaroe'd-din en deze werd in de plaats van den eersten tot Sultan verheven. 1

1 Horsfirkd verhaalt dit eenigszins anders uit Palembangsche bronnen, welke den schrijver van dit H. S. blijkbaar niet bekend waren. Bij hem heet de latere Sultan Raden Le mboe en is sprake van hulp van de Hollandsche Compagnie om den verdreven Sultan op den troon te herstellen, hier in het geheel niet vermeld. Als jaartal van den aanvang der regeering van Sultan Machmoed Badaroe'd-din wordt 1722 opgegeven (Tij d s chr. v. Ned. Indie, ja a rg. 1850 , b 1 z. 202 ), ofschoon Van RiJn van AlKemade hiervoor 1718 vermeldt (Tijdschr. Aardr. Genootschap, le serie, Dl. VII, blz. 68). Wellicht doelt hierop hetgeen min of meer gewijzigd vermeld wordt in het werk van E. Netscher, D e Nederlanders in Djohor van 1602-1865, b1 z. 49; ofschoon het anders opmerkelijk is, dat daarin Bangka, hetwelk volgens dit H. S. zoo herhaaldelijk met Djohor in betrekking stond, schier nergens wordt genoemd. 
Eenmaal bevestigd in het gezag droeg hij aan een Mantri op Wan Akoeb en zijn familie van Bangka-Kota te gaan afhalen en naar Palembang over te voeren. Hij bewees dezen allen veel eer en gaf de vrouwen o. a den titel van Jang en aan de mannen dien van Abang; overeenkomende met de Palembangsche titels Mas Ajoe en Mas Agoe's '. Tevens bepalde hij, dat de vrouwelijke nazaten alleen met lieden van hun eigen stam en de Sultans van Palembang in het huwelijk mochten treden.

Toen het bestuur behoorlijk geregeld was, vroeg de Sultan aan zijn echtgenoote, waar zij wilde, dat haar ouders en familieleden en in het algemeen alle afstammelingen van Wan Akoeb en Ibrahim zouden verblijven; waarop zij verzocht, dat die op Bangka mochten wonen.

Vervolgens werd een daartoe geschikte plaats uitgezocht op een kaap vóór den berg Menoembing, welke men in het Sijantansch antoe $\mathrm{e}^{\varsigma}$ noemde, door anderen uitgesproken als mantoe $\mathrm{e}^{\varsigma}, \mathrm{oentoe}^{\varsigma}$ en mento $e^{s}-$ mentoe $e^{s}$, hetgeen beteekent: "zoo, zoo, en daarheen, daarheen". Daarom noemde de Sultan dat oord Mĕntos en de Kaap Kaléan, daar het zand zich naar gelang van den moeson verplaatste (beraleh) ${ }^{2}$. Hij stelde er Wan Akoeb als hoofd aan, liet er een kampong bouwen en noodigde Abdoel Djabar, die nog te Sijantan was, uit zich met zijn vijf dochters en verdere bloedverwanten aldaar met der woon te vestigen. Herwaarts verhuisd, werd Datoe ${ }^{\varsigma}$ Dalam tot geestelijk opperhoofd van Bangka aangesteld, terwijl Wan Akoeb het oppertoezicht had over de tinmijnen, welke door de bewoners onder hunne Patih's en Batin's werden ontgonnen.

1 Volgens W. L. DE STURLfr (o. c. b 1z. 90) heeten te Palembang Mas Agoes de zonen van een Pangeran bij een vrouw uit de volksklasse en dragen hunne echtgenooten den titel van M a $\mathrm{S}$ Ajo e; Van Rijn van Alkemade (o. c. b1z. 55 ) noemt als zoodanig hen, die uit de verbintenis van een Raden met een bijwijf zijn voortgesproten. In het $\mathrm{R}$ esumé $\mathrm{n}$ a a r de rechten op den grond in Bangka wordt opgegeven, dat. alleen afstammelingen van den Sultan van Palembang aldus betiteId worden.

2 De toelichting in het H. S. door „bagitoe-bagitoe dan kas anak a s a na" kan moeielijk op iets anders dan een aanwijzing voor den roerganger betrekking hebben, al wordt dit niet bepaald gezegd. Evenals van het volgende $\mathrm{kalé} \mathrm{an}$ is de verklaring wel wat gezocht. HorsfikLd noemt als stichter van Muntok zekere Pa.Mento, aan wien de plaats haar naam zou ontleenen. Wat hij overigens (b1 z. 205) omtrent die stichting en de eerste bewoners mededeelt, komt in vele opzichten, ofschoon minder uitvoerig uiteengezet, met het hier vermelde overeen. 
Aan de hier en daar verspreide Maleiers werd gelast de bevolking te leeren, hoe te Djohor tin werd verkregen, nl. door het graven met een schopvormig werktuig uit een diepere ertslaag ${ }^{\mathbf{1}}$; de aldus verkregen erts werd versmolten en aan Sultan Mahmoed Badaroe'ddin verzonden. Deze bepaalde tevens dat elk huisgezin jaarlijks moest opbrengen een hoeveelheid tin ter zwaarte van 50 katies, waarvoor een stuk lijnwaad werd te goed gedaan ${ }^{2}$. De Maleiers waren hiervan vrijgesteld en de opbrengst van tin in het district Muntok stond de Sultan af aan Datoe ${ }^{\varsigma}$ Akoeb en zijn familie.

Dajang Berani en zijn volgelingen kregen Belinjoe tot woonplaats, maar overigens geen bijzondere voordeelen, zoodat zij hierover vertoornd niet lang daarna naar Djohor terugkeerden, bewerende dat de Sultan zijn belofte had verbroken.

Daar de opbrengst van tin niet bijzonder toenam, stelde Datoe' Akoeb aan den Sultan voor om in Djohor lieden van Sijam en Cochinchina te laten zoeken, die met den arbeid in de mijnen bekend waren, en deze naar Bangka over te voeren, ten einde de tinontginning te leiden. Toen de Sultan dit goedkeurde, zond Datoe' Akoeb zijn broeder Wan Sirin en droeg hem tevens op de afstammelingen van Wan Awang in Kambodja en Sijantan over te halen naar Bangka te verhuizen. Wan Sirin had het geluk hiermede zeer goed te slagen, zoodat hij verscheidene Sijameezen en Cochinchineezen naar Muntok bracht, die aan de mijnen te werk gesteld de verkregen hoeveelheid tin aanmerkelijk deden toenemen. Daardoor werd de Sultan genoopt geld beschikbaar te stellen voor het

1 Nog heden heeft men drieërlei wijze van bewerking, nl. 10 door het aanleggen van ko elit-mijnen, waar de erstlaag onmiddelijk onder de oppervlakte van den grond, hoogstens 6 voet diep, ligt; 20 van koelit-kolong-mijnen, waaruit tinerts verkregen wordt tot een diepte van 10 tot 14 vt.; en $3^{\circ}$ van kolong-mijnen, waarbij alleen de dieper liggende ertslagen worden opgegraven. De laatste bewerking is de kostbaarste, maar levert tevens de grootste winsten op. Uitvoerige beschrijvingen van de bewerking der tinmijnen en der gebruiken bij de mijnwerkers zijn te vinden in het $\mathrm{T} i \mathrm{dschr}$. v. Ned. Indie, jaarg. 1843, Deel II, blz. 392 en vlg. en ja arg. 1844 , Deel II, blz. 49 en vlg., in het werkje van Dr. J. H. Croockewri, Bangka, Malaka en Billiton, benevens in alle jaargangen van het $\mathrm{Jaarboek} v a n$ het $\mathrm{Mijnwezen}$ in N. Indie.

2 Die verplichting heeft geduurd tot het jaar 1812, toen door Sultan Ahmed Nadjmoe'd-din het eiland Bangka in volle souvereiniteit aan de Engelschen werd afgestaan. Sedert bewerken de echte Bangkaneezen geen tingronden meer en zijn het alleen de Maleiers ter hoofdplaats, waarvan enkelen nog tinerts delven, ofschoon op veel eenvoudiger en minder productieve wijze dan de Chineezen. 
aanwerven van Sijameezen en Chineezen, waarmede een Chinees van Palembang, Tjoeng Hoejoet, belast werd en waarvan het gevolg was, dat er vele Chineezen kwamen te Muntok, Belinjoe en Boenoet ${ }^{1}$. Zij kregen geld, rijst en andere benoodigdheden en aan de kongsi werd voor een pikoel tin vijf rijksdaalders uitbetaald ${ }^{2}$.

$\mathrm{Na}$ het overlijden van Datoe ${ }^{\varsigma}$ Dalam, wiens graf te Muntok tot heden in eere wordt gehouden, werd aan Datoe ${ }^{\varsigma}$ Akoeb het geestelijk gezag verleend, dat hij tegelijk met het toezicht op de mijnen uitoefende.

Daar de vorst van Koedoeng den oorlog had verklaard aan Sijantan en Kambodja, kwamen vele bewoners dier gewesten naar Muntok, alwaar zij zich met der woon vestigden, zoodat die plaats voortdurend grooter werd en bij de meerdere opbrengst van tin in welvaart toenam. Er ontstond evenwel herhaaldelijk twist tusschen de Maleiers en Chineezen, omdat de laatsten zich het tin wilden toeëigenen. De Sultan droeg deswege aan Datoe ${ }^{\varsigma}$ Akoeb op een fort te bouwen en dat van geschut te voorzien.

$\mathrm{Na}$ den dood van Wan Akoeb trad Wan Sirin in zijne plaats en deze werd later vervangen door zijn zoon Datoe ${ }^{\varsigma}$ Adji, terwijl hij in het genot bleef van al de vroeger bedongen voordeelen ${ }^{3}$.

De Sultan regelde nu het bestuur in dier voege, dat hij uit de afstammelingen van Ibrahim en Awang een keuze deed, en wel zekeren Otzman, dien hij in tegenwoordigheid van alle rijksgrooten tot $\mathrm{R}$ ang ga en Hoofd over geheel Bangka aanstelde, hem een rang gevende gelijk aan dien der der Rangga's in Palembang; terwijl hij hem begiftigde met een gouden hoofddeksel (kopijah), een kris, vier lansen en een sirihdoos, als teekenen zijner waardigheid. Voorts benoemde de Sultan zekeren Moehamad tot opziener te Muntok en gaf hem den titel van Demang.

Aan den Rangga werd de navolgende bevoegdheid gegeven :

$1^{\circ}$. dat hij in alle godsdienstige geschillen zou recht spreken en zelfs de doodstraf mocht opleggen;

1 Dit is waarschijnlijk de juiste naam der plaats, door prof. VETH, als onleesbaar in het handschrift van Horsfield in L o e moet veranderd ( $\mathrm{T}$ ij d s ch r. v. N. Indie, ja a rg. 1850 , blz. 206).

${ }^{2}$ De Sultan kreeg van de Compagnie bij levering te Palembang voor elken pikoel $13 / 3$ rijksd. en bij levering te Batavia 15 rijksdaalders; hij verdiende er dus heel wat op.

3 Uitvoeriger dan bij HoRsfield zijn in dit H. S. de namen der elkaar opvolgende hoofden op Bangka vermeld; waarschijnlijk is dit het gevolg daarvan, dat $\mathrm{H}$. zijn voornaamste inlichtingen te Palembang ontving. 
$2^{\circ}$. dat niemand buiten hem om als Kadi, Chatib of Moedin mocht optreden;

$3^{\circ}$. dat hij mocht beslissen in zaken betreffende het gewoonterecht der Maleiers te Muntok;

$4^{\circ}$. dat hij tinmijnen kon laten ontginnen en aanwijzen, waar het tin zou in ontvangst genomen en welke hoeveelheid te Muntok moest geleverd worden;

$5^{\circ}$. dat hij en de andere hoofden te Muntok voor eigen rekening tinmijnen ontginnen en tinerts uitgraven en het verkregen tin ten eigen voordeele mochten verkoopen;

$6^{\circ}$. dat hij elken dag van den Patih 12 heerendienstplichtigen kon verlangen;

$7^{\circ}$. dat belangrijke geschillen, waaromtrent de beslissing van den Sultan werd ingeroepen, eerst bij hem moesten worden voorgebracht;

$8^{\circ}$. dat hij eens in het jaar of eens in de drie jaren te Palembang zijn opwachting moest komen maken, hetgeen echter bij dringende dienstaangelegenheden meermalen kon geschieden;

$9^{\circ}$. dat het ten strengste verboden was dat eenig aanzienlijk Palembanger behalve de Sultan in het huwelijk trad met een afstammelinge van Wan Awang; en

$10^{\circ}$. dat, als de Rangga te Palembang kwam, zijn prauw mocht ankeren bij de aanlegplaats vóór het paleis en dat het niet noodig was, dat hij zich bij andere beambten vertoonde, maar rechtstreeks naar den Sultan kon gaan.

Vervolgens werden de noodige bepalingen gemaakt voor de Patih's, de Batin-Pasirah's en de Batin-Pengandang's of BatinKetjil, te weten :

I. Geen hoofd kan op Bangka benoemd worden zonder dat de goedkeuring van den Sultan van Palembang is verkregen.

II. Elk hoofd heeft zijn eigen volk onder zich; de Patih's staan boven de Batin-Pasirah en deze weder boven de Batin-Pengandang.

III. Elk der bedoelde hoofden moet eens in het jaar of eens in de drie jaren zijn opwachting bij den Sultan komen maken tot het doen van mededeelingen over den toestand van Bangka; zoo noodig kan dit echter meermalen plaats hebben.

IV. Alleen van gehuwde Bangkaneezen mag koelie- of heerendienst en belasting in tin geheven worden; bij echtscheiding of huwelijk hunner kinderen komen zij vrij. Vrouwen mogen bovendien het door haar bewoonde district niet verlaten.

V. De hoofden ontvangen hulp van de bevolking bij de bewerking 
hunner ladang's; voor den Patih en Batin-Pasirah moet elk gehuwde tien dagen in het jaar uitkomen, voor den Batin-Pengandang vijf dagen en voor den Gegading of Lengan éen dag in het oogstjaar.

VI. Bij niet voldoening hieraan wordt voor elken verzuimden werkdag een halve gulden of padie tot dat bedrag betaald.

VII. Evenzoo wordt door de bevolking aan de hoofden bijstand verleend tot het bouwen hunner woningen en van het raadhuis.

VIII. Jongelingen zijn van alle diensten vrijgesteld; boodschappen kunnen hun echter worden opgedragen.

IX. Zoo een Chinees een vrouw van Bangka als bijzit neemt, moet hij elk jaar 10 rijksdaalders of 33 gulden aan haar hoofd betalen.

X. Als een Maleier of een vreemdeling met een vrouw van Bangka wil huwen, moet hij aan haar hoofd 26 rijksdaalders als bedrag voor de kennisgeving betalen en als koopman aan de vrouw of haar vader 5 rijksdaalders; maar de Maleiers zijn vrij van alle diensten, behalve het verleenen van hulp in geval van oorlog of verzet. Bij huwelijken tusschen Bangkaneezen krijgen de hoofden niets en ontvangt de vrouw alleen de bruidschat.

XI. Bij echtscheiding moeten man en vrouw ieder een halven gulden aan het hoofd betalen: de man wordt dan vrijgesteld van koeliedienst. Zoo hij het echter om die reden doet, wordt hij met 12 rijksdaalders beboet en weder tot dien dienst verplicht. De eene helft der boete vervalt aan het hoofd, de andere aan zijn Mandoer.

XII. Als iemand zonder erfgenamen overlijdt, of wel dat deze onder een ander hoofd staan, zoo komt de erfenis aan het hoofd van de plaats, waar die persoon is overleden. Degenen, die niets nalaten, moeten echter op kosten van het hoofd worden begraven.

XIII. Als op zee of aan den wal iets bijzonders of van waarde wordt gevonden, dan wordt zulks in tweeën verdeeld; de helft voor het hoofd en de andere helft voor den vinder.

XIV. Als iemand in een andere plaats, dan waartoe hij behoort, ladang's aanlegt, moet de opbrengst in vieren worden verdeeld: een deel voor den eigenaar van den grond en de drie andere deelen voor den ontginner en degenen die hem helpen; dit gedurende den geheelen tijd, dat hij die ladang's bewerkt.

$X V$. Degene, die een gelofte doet aaan zijn hoofd of aan een heilige plaats, wordt, zoo hij die niet volbrengt, beboet met 6 tot 12 rijksdaalders: de helft voor het hoofd en de helft voor het volk. 
XVI. In alle gebruiksovertredingen, waarop de doodstraf staat, wordt beslist door den Sultan; alleen die, welke tevens op den godsdienst betrekking hebben, worden met goedvinden van den Sultan door het hoofd te Muntok berecht.

XVII. Boeten boven 24 rijksdaalders worden uitsluitend opgelegd door de Patih's en Batin-Pasirah's; maar zij mogen ook in kleinere geschillen recht spreken, als hun eigen lieden of de Batin-Pengandang's zulks vragen of wel als deze weigeren een beslissing te nemen.

XVIII. De Batin-Pengandang's mogen slechts tot een bedrag van 24 rijksdaalders boeten opleggen en ook niet beslissen in geval van kleinere boeten, als het geschil het rechtsgebied van een anderen Pasirah betreft,

XIX. Van alle vonnissen is beroep geoorloofd op den Sultan van Palembang of bij boeten in godsdienstzaken op den Rangga te Muntok.

$\mathrm{XX}$. Bloedschande (het zoogenaamde b o ej o eng of overspel met een bloedverwant, die het niet geoorloofd is te huwen) kan met den dood worden gestraft door den Mantri te Muntok, na bekomen goedkeuring van den Sultan.

XXI. Doodslag zonder kwaad opzet of uit drift, of omdat iemand scheidt van zijn zwangere vrouw, zonder voor haar voldoende te hebben gezorgd, zoodat zij ten gevolge daarvan sterft, wordt beboet met 120 tot 424 rijksdaalders; welke boete pembangoen heet en ten goede komt van de erfgenamen der overledenen.

XXII. Vechten met of zonder wapenen, dat een wond veroorzaakt, wordt beboet met 16 tot 22 rijksdaalders ten voordeele van den klager, d. i. de gewonde.

XXIII. Die boomen of aanplantingen beschadigt, moet de geschatte waarde vergoeden; als dit evenwel met opzet geschiedt, wordt de dader bovendien beboet met 20 tot 200 rijksdaalders ten voordeele van het hoofd, die de boete oplegt.

XXIV. Als opgeborgen of begraven goederen gestolen worden, moeten de daders die teruggeven en voor het ontbrekende de dubbele waarde als schadeloosstelling betalen; zij worden bovendien beboet met 24 tot 44 rijksdaalders: de helft voor het hoofd en de helft voor den eigenaar.

$X X V$. Als iemand honiggraten steelt, moet hij de geschatte waarde aan honig en was en bovendien 10 tot 55 rijksdaalders boete betalen. 
XXVI. Diefstal van vischnetten of van visch uit de fuiken en andere toestellen wordt beboet met 10 tot 48 rijksdaalders en vergoeding van het ontvreemde.

XXVII. Poging tot moord of brandstichting of andere onheilen wordt beboet met 6 tot 26 rijksdaalders ten voordeele van het hoofd, die het ontdekt. 1

1 Een nauwgezette vertaling der nu volgende artikelen was niet altijd gemakkelijk, omdat de tekst hier en daar minder duidelijk is door het gebruik van rechtstermen, die bij de sedert gewijzigde toestanden verloren gingen en in de woordenboeken ook niet worden verklaard.

Aan de welwillendheid van den controleur van Toboali, de heer J. J. van Hufres, dank ik eenige inlichtingen, die het hem gelukt is van bejaarde inlanders omtrent enkele woorden te krijgen en welke hierbij volgen.

So e mbang is "bloedschande".

Soembang boejoeng id. tusschen naaste bloedverwanten; ook tweelingen van verschillende sekse worden als b o e jo e $\mathrm{ng}$ beschouwd.

B o ejoeng p ĕmali of b. sing goel is een verboden betrekking tusschen meer verwijderde bloedverwanten, als $a$. oom en tante met nicht en neef, $b$. broeders- en zusterskinderen en $c$. tusschen zoogbroeder en zoogzuster; huwelijken van $b$. en $c$. waren toegelaten tegen betaling van boete.

S ing g o e 1, in het Woordb. door "stooten" verklaard, beteekent hier overdrachtelijk "stuitend tegen de zeden".

$\mathrm{Peng}$ a ng k at; nog heden zegt men van eene vrouw, die het met een ander houdt: soedah berangkat dari lakinja.

Palirang; denkelijk beter pawirang en dan "wat schaamte berokkent" of "schending der eerbaarheid".

Palirang kering is "schending der eerbaarheid door woorden" en palir a ng bas a hetzelfde "door daden".

$\mathrm{Pemandian} \mathrm{kasarangan} \mathrm{was} \mathrm{vroeger} \mathrm{de} \mathrm{gewone} \mathrm{uitdrukking} \mathrm{voor}$ "algemeene badplaats".

Temboeng lakoe is onbekend; wel temboeng in de beteekenis van „een stok van een vadem lengte, dikker dan een wandelstok". Wellicht moet dit $\mathrm{t}$ i m b a n g 1 a ko e zijn, d. i. „een gepleegde handeling of daad goed maken”.

Pengoewat is "iets, dat gehandhaafd of bekrachtigd moet worden".

Pijawang pětjah. Pijawang is het „hoofd van een vereeniging of gemeenschap", b. v. pijawang poekat = kapala poekat; ook ,degene, die vertrouwd wordt". In deze uitdrukking is weggelaten timba; het zou moeten zijn: pijawang petjah timba d. i. „een hoofd, die de bepalingen overtreedt en dus het in hem gestelde vertrouwen schendt".

Voorts wordt daarbij nog omtrent madoe soenggoeh, m. sijalang en m. papah (zie art. XXIII en XXV) aangeteekend:

Met deze uitdrukkingen worden geen verschillende soorten van honig bedoeld, doch alleen de wijze van winning of het recht daarop.

$\mathrm{Madoe}$ soenggoeh (ten rechte soengga u) is „een stok van \pm 2 vadem lengte, die tusschen de takken van een boom in uitstekende richting gebonden wordt, om de bijen te lokken daaraan hun nest te maken".

Madoe-sijalang (sij a lang hier zelden gebruikt, meer te Palembang) 
XXVIII. Ingeval van boejoeng-pemali of boejoengsinggoel, als een man overspel pleegt met een vrouw die in den echt moet treden, maar de stand der moeder is hooger of lager of wordt als gelijk aangenomen, zoo wordt hij beboet: het $\frac{3}{3}$ gedeelte voor het hoofd en $\frac{1}{4}$ voor de kampoeng-lieden; en eerst dan mag hij met die vrouw huwen.

XXIX. Ingeval van pengangkat, als een man overspel pleegt met de vrouw van een ander en het bewijs daarvan is geleverd, wordt hij beboet met de boete pengangkat, zijnde 72 tot 148 rijksdaalders: het $\frac{1}{4}$ gedeelte voor het hoofd; maar als die vrouw wordt veroordeeld haren nieuwen man te volgen, krijgt het hoofd niets en vervalt de boete aan haar vorigen man. Ook ontvangt de vrouw dan niets van de goederen van den laatsten, tenzij hij die zelf wenscht te geven en haar andeel in zijn schulden draagt; scheiden zij echter, omdat haar man haar verstoot, dan worden de goederen en schuldvorderingen in tweeën gedeeld.

XXX. Ingeval van palirang-basah, als een man overspel pleegt met een vrouw die in den echt moet treden, en zij zwanger wordt, maar zij niet genegen zijn te trouwen, wordt degene die niet wil huwen beboet met 16 tot 26 rijksdaalders ten voordeele van het hoofd. Wil echter de vrouw huwen en de man niet, dan komt de boete ten bate der vrouw: maar zij kunnen vrijgesteld worden van de boete, als ieder naar eigen goedvinden in het huwelijk treedt, in welk geval aan het hoofd 6 gulden wordt betaald. Bij een gedwongen huwelijk blijft de boete van kracht: de vrouw krijgt dan de helft en het hoofd de andere helft; is echter de vrouw eerst daartoe genegen en moet zij er later toe gedwongen worden, zoo komt de geheele boete aan het hoofd.

XXXI. Ingeval van palirang-kering, als iemand eens anders vrouw en kinderen of wel een vrijgezel onbehoorlijke dingen verwijt,

is "het recht op de nesten van een bijenboom, verkregen door den boom rondom den stam schoon te maken". Ditzelfde recht verkrijgt men op Bangka door bij den boom de wacht te houden en heet daar tang it of $\mathrm{s}$ a pon.

$\mathrm{Madoe}-\mathrm{papah}$ (ten rechte popoh) is "het maken van een teeken op den boom als recht van eigendom op de nesten". In plaats daarvan zegt men gewoonlijk madoe mempoeang of ,honig van een boom, waarvan de ontdekker de takken en de nesten, die er aanzitten, schoonmaakt en onderhoudt".

Wat betreft de titels der in het H. S. genoemde hoofden wijst de heer v. H. er tevens op, dat er tegenwoordig geen onderscheid meer wordt gemaakt tusschen batin-pasirah en batin-pengandąing jen dat de functie van g e g a ding of "adjunct-batin" sints 25 jaren vervallen is. 
wordt hij beboet met 3 tot 12 rijksdaalders ten voordeele van den klager; maar als zulks geschiedde tegenover de vrouw en kinderen van een hoofd, zoo stijgt de boete van 12 tot 24 rijksdaalders.

XXXII. In geval van singgoel, als iemand binnentreedt in een woning, waarin zich een meisje alleen bevindt, zonder haar leed te doen, wordt hij beboet met 4 tot 6 gulden. Dezelfde boete treft iemand, die zonder vergunning van den eigenaar in een woning op den buik gaat liggen. Somwijlen gebeurt het, dat de eigenaar weet dat de persoon pas gekomen en nog niet naar de rustbank is gegaan en dan kan hij hem gerust in zijn woning ontvangen.

XXXIII. Ingeval van pemandian-kasarangan, als een man naar een badplaats in of buiten de kampoeng gaat en bij het water gekomen geen teeken geeft, zoodat hij een vrouw ontkleed ziet, dan wordt hij met 6 tot 12 rijksdaalders beboet ten voordeele van de klaagster. Maar heeft hij zulks gedaan en zijn er buiten de badplaats sporen te vinden, dat hij dáár gewacht heeft, dan wordt hij van die boete vrijgesteld.

XXXIV. Ingeval van temboeng-lakoe, als iemand door zijn woorden of gedrag aanleiding geeft tot twist of beschaming in de kampoeng, dan wordt hij beboet met 2 tot 24 rijksdaalders : $\frac{3}{4}$ voor den aanklager en is voor het hoofd.

XXXV. Ingeval van pengoewat, als een vrouw verloofd is met een man en de verloving wordt verbroken, omdat zij zich terugtrekt en een ander huwt, dan wordt deze, zoo dit aan zijn toedoen is te wijten, beboet met 2 tot 24 rijksdaalders : de helft aan den eersten verloofde en de helft voor het hoofd.

XXXVI. Ingeval van pengangkat, als er in eenige kampoeng een erge ziekte heerscht of wilde dieren zijn, dan wordt midden op de wegen naar de kampoengs, welke nog niet door die ramp zijn getroffen, een afgeschild stuk hout geplaatst, ter voorkoming dat lieden uit de eerste naar de laatste gaan. Degene, die dit of een ander verbod overschrijdt, wordt beboet met 4 tot 40 rijksdaalders, te verdeelen onder de kampoeng-lieden.

XXXVII. Alle vonnissen van boeten niet hooger dan 120 rijksdaalders mogen de hoofden door gedwongen arbeid doen innen ter aflossing; voor hoogere bedragen gesehiedt zulks te Palembang of te Muntok, als het godsdienstzaken betreft.

XXXVIII. Al de genoemde boeten kunnen betaald worden voor $\frac{1}{4}$ in kontant geld en voor het resteerende met allerlei goederen, tegen een waarde, die veel hooger is dan de schatting. 
XXXIX. In zaken betreffende het pengangkat komt de boete aan den klager of zijn erfgenamen, maar kan ook aan het hoofd vervallen, als die gepaard gaan met boejoeng of pemali.

XL. Van boejoeng of pemali krijgt het hoofd de boete; maar voor de helft van het geld moet hij meel onder de kampoenglieden verdeelen, opdat zij daarvan kunnen eten bij wijze van zuiverings-middel.

XLI. Van de boete pe mbang oen voor overledenen krijgt het hoofd $\frac{1}{3}$, behalve voor de pembangoen in zake houtgewas of boomen; in zake diefstal krijgt het hoofd $\frac{1}{5}$ en bij palirang-basah krijgt hij het soms en dan weder niet; bij temboeng-lakoe en pengangkat krijgt het hoofd $\frac{1}{3}$.

XLII. Ingeval van pijawang-petjah, als een hoofd de genoemde wetten overtreedt, wordt hij gestraft met al de boeten voor de klagers en worden deze onder zijn lieden verdeeld, terwijl hij niets ontvangt; voor zijn moeite krïgt de ondergeschikte, die de beslissing neemt, 2 tot 12 gulden.

XLIII. De boeten voor de hoofden moeten in drieën verdeeld worden onder de ondergeschikte hoofden en de oudsten, die mede vonnissen; maar staat degene die beboet is onder den Pasirah, dan krijgt deze ${ }_{3}^{2}$; behalve als de Pasirah recht spreekt over lieden van den Batin-Pengandang, in welk geval de boete in tweeën wordt verdeeld, de helft voor hem en de helft voor den Batin. Evenzoo moet de Batin de boete van een door hem uitgesproken vonnis in drieën verdeelen: een deel voor de Mandoer's van den gestrafte en de andere deelen voor hem.

XLIV. De gemelde gebruikswetten zijn alleen geldig voor Bangkaneezen, maar niet voor de Maleiers te Muntok. Staan deze onder eenigen Pasirah of Batin, dan kunnen zij in zaken betrekking hebbende op den godsdienst de beslissing vragen van den Rangga te Muntok.

XLV. Aldus zijn door den Sultan vastgesteld de bevoegdheden van den Rangga, de Patih's en Pasirah's op het geheele eiland Bangka.

Met de voortgezette ontginning van nieuwe mijnen werd het aantal inwoners van Muntok grooter en waren er onder de Chineezen velen, die heimelijk tin stalen. Een zekere Chinees, met name Oen Asing ', was daardoor zeer rijk geworden, daar hij het gestolen

1 Ook Horsfikld noemt As ing, echter alleen in gunstigen zin, als de persoon die een betere bewerking der tinmijnen invoerde. 
tin verkocht aan de wangkang's, die Muntok aandeden. Op zekeren tijd ontstond hierover twist tusschen de Chineezen, Sijameezen en Palembangers, die in de mijnen te Beloeh werkten '. Velen werden gedood en hunne lijken geworpen in de rivier Semboesoe ${ }^{\varsigma}$. Aldus de schuld van Oen Asing gebleken zijnde, liet de Rangga hem gevangen nemen en naar Palembang brengen, waar de Sultan hem ter dood veroordeelde. Wegens zijn rijkdom werd hij echter door vele Mantri's te Palembang geholpen en ontging de doodstraf, maar zịn eigendommen werden verbeurd verklaard en hij zelf verbannen naar de doesoen Belid 2, van waar hij niet naar Bangka mocht terugkeeren.

Ter beveiliging tegen de zeeroovers, die de prauwen net tin overvielen, vervaardigden de Maleiers een groot vaartuig; en zoolang de Rangga het bestuur in handen had, nam de opbrengst van tin voortdurend toe en ging de handel te Muntok steeds vooruit.

Sultan Mahmoed Badaroe'd-din was inmiddels opgegaan tot zijn vaderen en vervangen door zijn zoon, met name Soehoenan Ratoe Achmad Nadjmoe'd-din ${ }^{3}$, die een vrouw van Muntok nam, genaamd Mas Ajoe, dezelfde naam als het kanon, waarvan boven gesproken is. Tijdens dezen Sultan was de Rangga van Muntok al oud geworden en ook van de andere hoofden waren er velen vergrijsd, zoodat zij moeilijk toezicht konden houden op de werkzaamheden, of gestorven.

Daarom overwoog de Sultan, dat het beter was te Muntok een Temenggoeng aan te stellen, die het bestuur over Bangka zou uitoefenen; waartoe hij een afstammeling van Wan Awang uitkoos, genaamd Abang Pang Besar. Deze werd tot Temenggoeng verheven en zijn naam veranderd in Temenggoeng Dita Menggala. Zijn rang werd gelijkgesteld aan dien der Temenggoeng's in Palembang en zijn macht kwam overeen met die van den vroegeren Rangga. Onder hem stelde de Sultan een Penghoeloe en een Imam aan en gaf tevens vergunning tot het bouwen eener moskee te Muntok, waarvoor de houtwerken voor de helft van Palembang kwamen.

Tevens werd, ondergeschikt aan den Temenggoeng, een Palem-

1 Beloeh (het Belo der kaarten) is een kampong in het district Muntok, ten zuidoosten van de hoofdplaats.

2 Vermoedelijk een verkeerde spelling voor het in beschrijvingen van Palembang voorkomende Bliti, zijnde een kampong in het district Ampat-Lawang , een bekend ballingsoord voor bij den Sultan in ongenade gevallen rijksgrooten.

3 Volgens het $\mathrm{T}$ ij d s chr. v. N. Indie, ja a r g. 1850, b 1 z. 208 , overleed eerstgenoemde in 1756 en duurde de regeering van zijn vervanger tot 1776 ; VAN RIJN VAN ALKEMADE geeft hiervoor respectievelijk de jaren 1753 en 1778 (1. c. b1z. 68$)$.

6e Volgr. I. 
banger tot Djenang of Opzichter benoemd, om toe te zien op den arbeid in de mijnen en het tin in ontvangst te nemen.

Tegelijk met deze regeling werd de titel van Patih in dien van Depati veranderd en deed de Sultan voor deze betrekking een keuze uit Bangkaneezen van goede afkomst, Hij vond er twee; één werd Depati te Pakoes met zes Batin-Pengandang's onder zich en de tweede werd met den titel van Karija gelijkgesteld met den titel van Batin; verder kreeg Depak ' een Depati met zes Batin-Pengandang's, Pandji een Pasirah met drie Batin-Pengandang's en Muntok een Batin-Pasirah met vijf Batin-Pengandang's.

Voorts droeg de Sultan den Temenggoeng Dita Mengala op, over het geheele eiland Bangka een nauwkeurig onderzoek in te stellen naar de plaatsen, waar tinerts kon verkregen worden. Dientengevolge werden mijnen ontgonnen ten oosten van Muntok te Pahit, Beloeh en Tempilang en ten westen van Muntok te Bijat, Boenoet, Bendoel, Remboet en Soengei-Boeloh ${ }^{2}$. Bovendien werd den Batin-Pasirah van Pandji gelast te Pandji, den Depati van Depak te Lajang, Soengei-Lijat, Tjengal en Pangkal-Pinang, en den Depati van Pakoe $^{\varsigma}$ te Koebak, Balar en Toeboealih-Lama mijnen te ontginnen; behalve de oude mijnen te Oelim, Bangka-Kota, Djeroek en KotaWaringin. De Sultan zond nu Demang's en Djenang's om de werkzaamheden te leiden en tevens Chineezen, Sijameezen, Cochinchineezen en Maleiers.

In dien tijd tijd had het Palembangsche hoofd, die het toezicht hield, eigendunkelijk de belasting verhoogd tot drie stukken tin per man; de twee stukken betaalde hij zelf en deed met den verkoop in het geheim zijn voordeel.

Dit ging zoo door, omdat eigenlijk niemand verstand had van de zaak behalve Oen Asing, de vroeger verbannen Chinees. Daarom vroegen de Chineezen of hij mocht terugkeeren en opnieuw als hun hoofd optreden.

Aangezien toenmaals herhaaldelijk zeeroovers, tot zelfs in de mijnen, het tin wegroofden en er een gerucht ging dat de vorst van Djohor, genaamd Jang Dipertoewan Radja Adji, een inval wilde doen in Palembang en Lingga, na vooraf Muntok te hebben bemachtigd, zoo ging Temenggoeng Dita Menggala zelf naar Palembang om den Sultan over deze aangelegenheden te spreken.

$1 \mathrm{D}$ e p a k is een onderafdeeling van het district Soengei-Lijat.

2 Deze plaatsen liggen in de tegenwoordige districten Muntok en Djeboes; alleen Pahit en Bendoel zijn niet op de kaarten aangegeven. 
De Soehoenan stemde dadelijk toe in den terugkeer van Oen Asing, vond het goed dat te Muntok een steenen fort gebouwd werd ter vervanging van het oude, dat van hout was opgetrokken, en gaf last aan zijn hoofden om met hun prauwen rondom het eiland Bangka de wacht te houden; terwijl hij voor het werkvolk 1000 rijksdaalders en 100 pikoel rijst beschikbaar stelde.

Daar Oen Asing zich getrouw van zijn taak kweet, werd hij spoedig tot Kapitan verheven en hem gelast te Beloeh een pakhuis te bouwen, waarvan de ruïnes nog heden te zien zijn.

Toen de vorst van Djohor bij zijn aankomst al die toebereidselen zag, zond hij iemand naar Temenggoeng Dita Menggala met het bericht, dat hij hem wenschte te ontmoeten, daar hij allerlei zaken noodig had welke hem ontbraken. De Temenggoeng antwoordde, dat het hem niet te doen was den vorst niet te ontvangen, maar vreesde dat de Sultan van Palembang hem dit euvel zou duiden; dat hij echter dadelijk zou zenden al hetgeen den vorst ontbrak. Op het hooren van dit antwoord was de vorst zeer vertoornd, en stelde zijn troepen in slagorde van af de Laoet Mento ${ }^{\text {-Asin }}$ tot aan de Laoet Soengei-Mentos. Toen de hoofden, die in het fort de wacht hielden, dit zagen, laadden zij terstond het geschut om te vuren, maar een hunner, Intje ${ }^{\varsigma}$ Loeng Djafar, verbood zulks, om reden het nog niet zeker was wat er zou geschieden, en omdat bovendien niet mocht vergeten worden, dat Jang Dipertoewan Radja Adji afstamde van de vorsten van Djohor, waar de bewoners van Muntok ook van daan kwamen; zoodat het beter was niet te beginnen, maar eerst af te wachten hetgeen zou volgen. Daar de Temenggoeng vreesde dat het stellig op een strijd zou uitloopen, ging hij met alle eerbiedsbetooning naar boord bij Radja Adji zijn opwachting maken en gaf opheldering, waarom zij bang waren voor den Soehoenan, van wien zoovelen afhankelijk waren en onder wiens bestuur voortdurend rust en welvaart heerschten, terwijl hij Radja Adji dringend verzocht de reede van Muntok te verlaten.

Toen deze dit hoorde, begreep hij dat de Temenggoeng de waarheid sprak en was hij zeer verheugd; hij raadde zelfs aan de bestaande gebruiken en gewoonten nauwgezet te blijven volgen.

Radja Adji veranderde nu zijn plan om Palembang aan te vallen en vertrok naar Pontianak; maar velen zijner hoofden bleven zwerven in de wateren van Bangka, tot last van de mijnwerkers, die zij dikwerf van hun tin beroofden. De Temenggoeng vroeg om die reden vergunning aan den Soehoenan om op alle plaatsen, waar 
pakhuizen waren, aarden versterkingen te bouwen, welke achtereenvolgens tot stand kwam te Belinjoe, Tempilang, Bijat, Boenoet, Bendoel, Soengki ', Remboet en later nog te Klabat.

$\mathrm{Na}$ het overlijden van Soehoenan Achmad Nadjmoe'd-din kwam zijn zoon Soehoenan Moehamad Bahaoe'd-din op den troon ${ }^{2}$, en evenzoo werd Temenggoeng Dita Menggala vervangen door zijn zoon Abang Ismael, met den titel van Temenggoeng Kerta Menggala. De nieuwe Soehoenan nam tot vrouw een kleindochter van Temenggoeng Dita Menggala, genaamd Jang Pipah, en veranderde haar naam in Mas Ajoe Dalam.

Daar Temenggoeng Kerta Mengala zich weinig om den gang van zaken bekommerde, eigende de Depati van Depak, Anggoer, zich zoowel uit de belasting als uit de mijnen veel tin toe, dat hij verkocht aan de zeeroovers of Lanoen ${ }^{3}$. Den Soehoenan kwam zulks ter oore, waarom hij van Palembang zekeren Kemas Ismael met vele menschen zond om dien Depati te tuchtigen. Deze werd gewond en vluchtte met vrouw en kind naar de Lanoen's; zijn kind, genaamd Bahrin, was pas geboren, doch hij stierf kort daarop.

Het duurde evenwel niet lang, of de Lanoen's kwamen in groot aantal terug om Bangka te bemachtigen ${ }^{4}$. Zij verzamelden zich te Lepar en Billiton en overvielen van daaruit de mijnwerkers te Toboali en Koba, welken zij veel overlast veroorzaakten. De Soehoenan zond toen een Pangeran, met name Adi Widjaja, met vele prauwen naar de genoemde eilanden, om aldaar den arbeid in de mijnen te beschermen, en deze stelde tevens in al de mijndistricten Palembangsche mantri's aan, behalve in het district Muntok, van

$1 \mathrm{~S}$ oe $\mathrm{ngki}$ is een rivier met gelijknamige kampoeng in het westen van het district Muntok, ten noordwesten der hoofdplaats, en $\mathrm{K} 1 \mathrm{a}$ b a t een onderafdeeling van het district Djeboes, aan de baai van dien naam.

2 De regeering van dezen vorst duurde volgens $\mathrm{T}$ ij d s chr. N. L., 1. c. tot 1803 en volgens VAN RIJN vaN ALKEMAde tot 1805.

3 Over den smokkelhandel in tin, ook met de Engelschen, zie het R a p p rt van Staringh in $\mathrm{T}$ ij d s chr. v. Nederl. Indie, ja a rg. 1880 ; waarin o. a. op blz. 23 wordt aangeteekend, dat hij op zijn reis naar Palembang drie Engelsche schepen onder Muntok had zien ten anker liggen. Reeds vroeger maakten zij zich hieraan schuldig; zie E. NETSCHER, o. c. b1 z. 167 , noot.

4 De vermelding der redenen, welke tot de invallen der Lanoen's aanleiding gaven, wijkt zoozeer af van de lezing van Horsfield (T ij dschr. v. N. I. 1850), dat het moeielijk is beide berichten onderling te vergelijken. Ik houd echter deze voor degene, die het meeste vertrouwen verdient, daar H. op blz. 213 aanteekent, dat zijn verhaal louter berust op mondelinge mededeelingen te Palembang verkregen. 
af de rivier Kampa ${ }^{s}$ tot aan Tempilang. Ook dagteekent van dien tijd de benoeming van Chineesche hoofden, met den rang van Kapitan en Kongsi ${ }^{1}$ en de vergunning om met tinnen pitis te betalen ${ }^{2}$, welke bij vertrek of verhuizing tegen geld konden ingewisseld worden.

Bangka nam nu voortdurend in welvaart toe, zij het ook dat de bewoners nog veel te lijden hadden van de zeeroovers. Daar de Temenggoeng niets om zijn verplichtingen gaf, had een neef van hem, genaamd Abang Abdoel Gani of Abang Tawi, zich van het gezag meester gemaakt, zoodat velen hem als het eigenlijke hoofd gehoorzaamden.

Een afstammeling van Datoe ${ }^{\varsigma}$ Akoeb, genaamd Abdoel Rachman of Abang Koembang, gedroeg zich evenzoo, alsof hij aan het hoofd der zaken stond, en velen volgden hem, daar hij van de eerste stichters van Bangka afstamde. Als gevolg hiervan waren er drie hoofden, die het bestuur in handen hadden. De Temenggoeng beklaagde zich wel bij den Soehoenan over deze inmenging, maar wegens zijn onverschilligheid voor de hem opgedragen taak werd op die klachten geen acht geslagen. Wel is waar gaf die verdeeldheid aanleiding tot twist, maar het kwam niet tot een opeulijken strijd; alleen overviel Abang Tawi herhaaldelijk de Chineesche wangkang's. Hij ging zelfs naar Trengganau, om het graf van zijn vader in orde te brengen en deed op de terugreis Lingga aan, waar hij met den Jang Dipertoewan vriendschap sloot.

Te Muntok wedergekeerd, verzocht hij aan den Soehoenan vergunning om aldaar een aarden fort te bouwen, hetgeen werd toegestaan. De Temenggoeng en zijn schoonzoon Radja Ali wezen er den Soehoenan op, dat zij vreesden dat zulks geschiedde, om reden Abang Tawi zich met behulp van Lingga tegen Palembang wilde verzetten. De Soehoenan liet hem daarop roepen en hij werd zonder verder onderzoek vervoerd naar de doesoen Boeri en om het leven gebracht. Op het hooren van dit bericht wilden de bloedverwanten en aanhangers van Abang Tawi te Muntok naar Lingga verhuizen. De Soehoenan zond echter een Arabier, genaamd Said Ali, derwaarts om hen te overreden te blijven, in welk geval vrij-

1 Nog heden worden de Luitenants der Chineezen op vele plaatsen als Kongri toegesproken.

$2 \mathrm{Pit}$ is is volgens VON DE WALL een soort munt van onedel metaal, bij de komst der Portugeezen in den archipel algemeen gangbaar. Vergl. ook VkTH, J a va, I, b1 z. 490 . 
stelling werd verleend van alle verplichte diensten; hetgeen ten gevolge had dat alleen de naaste bloedverwanten naar Lingga gingen, met behulp van zekeren Panglima Raman, die hen van prauwen voorzag om den overtocht te maken. Het vertrek had plaats op den $18^{\text {en }}$ dag der maand Ramadan van het jaar $1258^{\prime}$. De Sultan van Lingga wees hun een verblijfplaats aan op het eiland Singkep, waar zij tot heden wonen, en tinerts vonden, die zij bewerkten.

Nog altijd vertoornd op den Soehoenan wisten deze lieden den Sultan van Lingga over te halen hem Bangka te ontnemen, waartoe tal van vaartuigen werden uitgerust, die het eerst Belinjoe aantastten en van daar uit andere plaatsen bemachtigden, met uitzondering van Muntok. Het gevolg hiervan was, dat overal forten en kampoengs verwoest werden, dat er veel tin werd weggeroofd, en dat de Bangkaneezen zich gingen verschuilen in de bosschen en hun ladang's niet meer bewerkten. Daardoor ontstonden hongersnood en pokziekten, welke velen ten grave sleepten. Tot het uiterste gedwongen gaven de Bangkaneezen zich over aan Panglima Raman of aan de zeeroovers. Eerst toen daagde er hulp op van Muntok, over land en over zee, en werden de vluchtelingen in de omringende kampoengs verzorgd. Eindelijk kwamen er ook prauwen met troepen uit Palembang, onder aanvoering van Ngambehi Hasan en Ngambehi Abdoellah, met wien zich vereenigde Raden Djafar, een afstammeling van den Soehoenan en een vrouw uit Muntok, die wegens misdrijf uit Palembang had moeten vluchten.

Daardoor kwam aan den strijd een einde, maar intusschen waren vele Bangkaneezen vermoord of gevankelijk weggevoerd naar Lingga Riouw, Pontianak, Sambas en Djambi, zoodat geschat wordt dat er slechts een derde van de bevolking overbleef. De twee Ngambehi's gingen terug naar Palembang en werden verheven tot Temenggoeng: alleen Raden Djafar bleef te Muntok, zich als een vorst gedragende, hetgeen den Soehoenan echter niet kon schelen. Wel nam hij den mijnwerkers veel tin af en verkocht dit ten eigen bate, maar de Soehoenan was bevreesd voor nieuwe onlusten en deed alsof hij er niets van wist.

Inmiddels was een Boegineesche vorstentelg, genaamd Aroeng Mempoe, wegens slechte handelingen uit zijn land verjaagd en naar Lingga gevlucht, alwaar hij woonde. Hij haalde de op Lingga en

${ }^{1}$ Dit jaartal is stellig fout, daar het zou overeenkomen met $1840 \mathrm{~A}$. D.; in den verderen loop van het verhaal is juister het jaar $1216 \mathrm{~A}$. H. vermeld. 
Singkep aanwezige Bangkaneezen over Muntok te overvallen en verbond zich daartoe met den genoemden Panglima Raman. Hij vertrok in het jaar 1216 (1801 A. D.) met vele prauwen, waarvan de meesten afdreven naar Belinjoe en Soengei-Lijat, zoodat hij slechts met één vaartuig te Muntok aankwam. Daar hij niet wist waar hij kon ankeren, bleef hij op een plaats, die thans Laoet Ajer-Boegis heet, de komst der andere prauwen afwachten. Hij vroeg zijn vaartuig aldaar op het droge te zetten, naar hij voorgaf om een lek te herstellen, maar de Temenggoeng en Raden Djafar stonden zulks niet toe, daar zij wisten welke plannen hij had, en gaven bevel hem weg te jagen, waarmede Demang Minjak werd belast. Hierop vertrok Aroeng Mempoe naar Karang Adji ', vergezeld van den Demang. Doch beiden kregen twist en de vrouw van Aroeng Mempoe werd getroffen door een kogel, afgeschoten uit de prauw van Demang Minjak. Hierover vertoornd, keerde Aroeng Mempoe terug met al de prauwen, die hij kon bijeenbrengen, en ging met zijn volk aan wal, waar hij een aanval deed op Muntok en vele huizen in brand stak, terwijl de bewoners in de Kota-Sariboe stand hielden. Een uitval onder twee hoofden, met name Joenas en Belaka Moehamad, had ten gevolge, dat de Boegineezen geslagen werden en naar hun vaartuig vluchtten, de dooden en gewonden achterlatende. Een halve maand later kwamen er troepen van Palembang, welke de andere prauwen van Belinjoe en SoengeiLijat verjoegen.

Ofschoon Raden Djafar voortging met zich tin toe te eigenen, deed de Soenan of hij er niets van wist. Wel zond deze vele Raden's van Palembang om te Toboali de wacht te houden, wier hoofden Raden Keling, Raden Achmad, Raden Badoer, Raden Ali en Raden Moehamad Sakbah aan Raden Djafar het verzoek deden, om zich naar Palembang te begeven. Deze wilde evenwel niet, bevreesd dat men hem misleidde. Later stierf hij op een reis van Djeboes bij Kaap Bijat en werd zijn lijk in een kist naar zijn familie te Palembang gezonden ${ }^{2}$.

Nadat Soenan Mohamad Bahaoe'd-din vervangen was door zijn

$1 \mathrm{Karang} \mathrm{Adji} \mathrm{(K.} \mathrm{Hadji} \mathrm{der} \mathrm{kaarten)} \mathrm{is} \mathrm{een} \mathrm{rif,} \mathrm{bewesten} \mathrm{Tandjoeng}$ Kalean gelegen.

${ }^{2}$ Het is opmerkelijk, dat in het H. S. geen enkele maal de Hollandsche Compagnie wordt genoemd, die toch sedert lang met den Sultan van Palembang voor het aankoopen van tin in betrekking stond; vermoedelijk het gevolg daarvan, dat rechtstreeksche inmenging in Bangkasche aangelegenheden niet plaats had. 
zoon Soenan Machmoed Badroe'd-din ', nam de laatste tot vrouw een dochter van Hadji Abdoellah, genaamd Jang Tje ${ }^{\varsigma}$, een kleindochter van Temenggoeng Kerta Menggala en van moederszijde van Datoe $^{\varsigma}$ Koembang, en verhief die tot Mas Ajoe Ratoe. De Temenggoeng werd toen vervangen door zijn zoon Taib, die den titel kreeg van Temenggoeng Kerta Widjaja en onder hen werd zijn oom Abang Moehamad Tsaleh tot Rangga Tjetra Nindijata, en een zoon van Datoe $^{\varsigma}$ Koembang, met name Abang Joenas tot Demang Wirada Perana aangesteld, aan welken zijn zwager, genaamd Abang Moehamad, als schrijver werd toegevoegd. De zoon van den Depati, met name Bahrin, die gevlucht was, kreeg vergiffenis en werd opnieuw tot Depati van Depak benoemd.

Niet lang daarna vluchtte een anderen Raden uit Palembang, met name Raden Wahab, omdat zijn zoon Raden Moehamad het met een vrouw van den vorst hield. Hij vertrok met zijn zoons, Raden Achmad en Raden $\mathrm{Mo}^{\varsigma}$ naar Riouw, waar hij omtrent drie jaren bleef. Toen ging hij met vele Boegineezen naar Toboali, met het doel hier tin te rooven en deze plaats te overvallen. Raden Keling hield daar het toezicht en gaf van dit plan kennis aan den Soenan, die gelastte hem met al zijn verwanten te vermoorden. Raden Keling volgde dit letterlijk op, zoodat allen om het leven kwamen, behalve Raden Achmad, die naar Riouw vluchtte.

Er was in dien tijd zekere Pangeran Moehamad van Palembang naar Muntok gegaan om een zuster van den Demang te huwen, hetgeen hem door den Soenan zeer euvel werd geduid, als in strijd met de vroeger vastgestelde bepalingen. Die vrouw werd hem daarom ontnomen en naar Palembang vervoerd, zonder hem te vergunnen langer bij haar te blijven. Pangeran Moehamad week om die reden uit Palembang en vestigde zich te Kedah. Er waren toen niet zoo heel veel Chineezen meer te Muntok en tijdens het bewind van dezen Soenan en op aandringen van Pangeran Moehamad en van Abdoel Raoep, de zoon van den vermoorden Abang Tawi, die Palembang wilden aanvallen, kwamen de Engelschen onder den Majoor Mir met geschut en paardenvolk te Muntok, voorgevende dat zij slechts eenige dagen zouden blijven om met den Soenan in overleg te treden ${ }^{2}$. De hoofden te Muntok antwoordden, dat zij

1 Deze troonverwisseling had plaats in 1803 (of 1805 , z i e noot, b $1 \mathrm{z} .145$ ) bij den d o od van Bahase'd-din, in het H. S. niet vermeld.

$3 \mathrm{Na}$ den moord op de Hollandsche bezetting (14 September 1811) kwamen de Engelsche Gommissarissen te Palembang, die echter onverrichter zake moesten 
het niet verboden maar evenmin toestonden en dat vooraf de toestemming van den Soenan moest verkregen worden. Intusschen maakten de Engelschen een fort aan kaap Kalean.

Van den Soenan kwam bericht, dat hij er niets aan kon doen, daar het te Palembang nog niet in orde was. De Engelschen trachtten nu de hoofden te Muntok gerust te stellen en de Majoor vroeg om een Maleischen schrijver, waartoe de Demang zijn zwager Abang Moehamad aanwees. Majoor Mir liet nu kennis geven, dat hij al het aanwezige tin wilde koopen voor 16 rijksdaalders de pikoel, zooals de Soenan gewoonlijk betaalde en dat hij genegen was op het product voorschot te verleenen. De hoofden te Muntok vonden dit goed en er werd veel tin in de Engelsche schepen geladen. Inmiddels viel Majoor Mir met Pangeran Moehamad en Abang Abdoel Raoep de hoofdplaats Palembang aan, maar keerde kort daarop gewond naar Muntok terug, alwaar hij spoedig aan de bekomen wonden overleed.

Zijn vervanger, met name Robison, kwam weldra van Batavia en bestuurde het eiland Bangka. Ook deze tastte Palembang aan en overwon het, waardoor Bangka in handen der Engelschen viel. Alleen hielden zij zich niet aan de afspraak met Majoor Mir, om te Muntok 16 rijksdaalders voor de pikoel tin te betalen, en werd de prijs voor geheel Bangka op 8 rijksdaalders vastgesteld. Daardoor hadden de bewoners van Muntok veel schade, daar zij met de mijnwerkers waren overeengekomen 11 rijksdaalders per pikoel te geven en had dit ten gevolge, dat zij den mijnarbeid lieten varen. De Engelschen plaatsten op elke pangkal ${ }^{1}$ een beambte en soldaten en hunne vaartuigen bekruisten de zee; ook regelde de Majoor het bestuur over het geheele eiland.

terug keeren. Daarop werd een expeditie georganiseerd, die den $15^{\text {en }}$ April 1812 ter hoofdplaats verscheen. De Sultan vluchtte en werd van den troon vervallen verklaard. Bij het contract, dat den 17en Mei tusschen Kolonel Gillespie en den nieuwen Sultan tot stand kwam, deed de laatste afstand van de souvereiniteit over de eilanden Bangka en Billiton. De hoofdmacht keerde toen naar Java terug, maar een deel der troepen zette de vervolgingen tegen den gevluchten Sultan voort en tastte de sterkte, waarin hij zich verschanst had, aan; doch na het sneuvelen van den Kapitein Meares trokken de troepen af (H. D. Levyssohn Norman, de Britsche heerschappij op Java en Onderheerigheden, b1z. 9 1). Volgens Lange (o. c. blz. 2 1) werd Kapitein Meares echter na zijn terugkomst tot Resident van Bangka en Palembang aangesteld en overleed hij kort daarna te Muntok aan de gevolgen van in den strijd bekomen wonden. Dit laatste wordt door het $\mathrm{H}$. S. bevestigd.

$1 \mathrm{P}$ a n g k a 1 heet de plaats in de nabijheid van een of meer mijnen, waar het bestuur gevestigd is. 
Daar de Temenggoeng al oud was, werd deze niet meer erkend en alleen de Rangga en de Demang als hoofd behouden; voorts werden nog Abang Kamal Oedin en Abang Moehamad, de schrijver, aan hen toegevoegd, zoodat er vier hoofden te Muntok waren, die elk een afzonderlijken werkking hadden. Ook begon men een pakhuis te bouwen en woningen voor de officieren en soldaten.

Daar Bangka nu voor goed onder Engelsch beheer was geraakt, verzochten de hoofden of de Bangkaneezen, die vroeger naar Lingga waren verhuisd, zoo zij zulks verlangden, naar Muntok mochten terugkeeren. De Majoor stond dit toe en velen kwamen van Lingga en Singkep naar Bangka over. Alle districten onderwierpen zich nu aan de nieuwe regeling, behalve Kota-Beringin, waar dit met veel tegenzin geschiedde, daar zich op die plaatsen meerdere afstammelingen van de vorstelijke familie te Palembang bevonden. Onderwijl werd een Engelsch schip, dat bij Billiton strandde, afgeloopen, vermoordden de zeeroovers den kapitein en den stuurman en verkochten zij de matrozen als slaven. Gevraagd om de laatsten in vrijheid te stellen, gaf de Depati van Billiton hieraan geen gehoor, waarom de Majoor troepen zond om Billiton te tuchtigen; bij welke gelegenheid de Depati werd gedood en door Radja Akil velen der gevangenen naar Muntok werden teruggebracht.

De Engelschen voerden vele Chineezen aan, die zij naar de pangkal's stuurden om de mijnen te bewerken, en van toen af kwamen te Muntok ook chineesche handelaars en anderen, die in den omtrek dier plaats groententuinen aanlegden. Niet lang daarna gaven de Engelschen Bangka en Palembang aan de Hollanders over, toen Palembang op nieuw in verzet kwam tegen den Edelen Heer Muntinghe, die moest terugtrekken en te Muntok bleef ${ }^{1}$. Later vertrok hij weder naar Palembang met twee schepen en nam de beide hoofden Wira Di Perana en Abang Moehamad mede, maar de strijd nam nog geen einde. De Edele Heer ging terug naar Batavia en gedurende meerdere jaren was het oorlog met Palembang.

1 Edele $\mathrm{He}$ er (of volgens de inlandsche uitspraak Edeler) is tot nog toe altijd de gewone betiteling van een Lid in den Raad van Indie. De hier bedoelde was Mr. H. W. Muntinghe, die in Juni 1818 te Palembang kwam om als Kommissaris van de Hooge Regeering aan het wanbestuur van den Sultan een einde te maken; hetgeen eerst door de expedities van 1819 en 1821 volkomen gelukte. Ofschoon de Schr. van het H. S. blijkbaar van de latere gebeurtenissen te $\mathrm{Pa}$ lembang niet goed op de hoogte is, acht ik het overbodig hier te herhalen, wat in vele werken en tijdschriften zoo uitvoerig is beschreven. 
Destijds was Resident van Bangka de Heer Smissaert ', maar op zekeren dag, dat hij van Djeroek kwam, werd hij in de kampoeng Poeding vermoord door een afgezant van Depati Bahrin en Demang Singa Joeda, en zijn hoofd door den Batin Tikal van Bangka-Kota naar Palembang gebracht. Nu kwamen er vele oorlogschepen met een Generaal te Muntok om Palembang te tuchtigen en, nadat dit land bemachtigd was, werden op Bangka eerst Toboali en daarna Kota-Waringin aangevallen. De laatste plaats kwam evenwel niet in handen der Hollanders, daar velen hunner aldaar gedood werden. Wel geschiedde zulks eenigen tijd later, met behulp der inlandsche troepen, zoodat de oproerlingen vluchtten naar Djeroek, alwaar zij, in het nauw gebracht, zich aan Abang Moehamad overgaven. Alleen Depati Bahrin kwam eerst na vele jaren in onderwerping?

\section{Op de kaarten van Bangka en in de ter vergelijking geraadpleegde werken ontbreken de volgende in het $\mathrm{H}$. S. voorkomende namen:}

$\begin{array}{cl}\text { Boekit } & \text { Semoegiri. } \\ \text { Goenoeng } & \text { Kalidang. } \\ \text { Kampoeng } & \text { Bendoel. } \\ \text { " } & \text { Boenoet. } \\ " \prime & \text { Pahit. } \\ \text { " } & \text { Penjampar. } \\ \text { " } & \text { Poenggoer. } \\ \text { " } & \text { Tjengal. } \\ \text { Poelau } & \text { Bamban. } \\ \text { " } & \text { Semboeang. } \\ \text { Soengei } & \text { Bentilan. } \\ \text { " } & \text { Kampa } \\ \text { " } & \text { Semboesoe. }\end{array}$

1 Bijzonderheden omtrent den dood van Resident Smissaert vermeldt Dr. ERP (o. p. S. 198). In zijn plaats trad de Overste Keer, die nevens het burgerlijk ook het militair beheer voerde.

${ }^{2}$ Depati Bahrin en zijn zoon, Depati Amir, verzetten zich lang tegen het Nederlandsch gezag en eerst in 1828 werd met hen een wapenstilstand gesloten, waarbij $z i j$ een geldelijken onderstand kregen en de belofte aflegden van zich te onderwerpen. Eerst van af dien tijd heerscht er rust op het eiland Bangka. 


\section{INSTRUCTIE VOOR DEN RANGGA.}

1 Perkara. Itoe Rangga ada koewasa di atas segala perkara oegama dan boleh memoetoeskan sampei pada perkara mati.

2 Perkara. Lain orang tiada boleh mendjadikan kadi atawa chatib dan moedin melainkan itoe Rangga boleh mendjadikan dengan koewasa sendiri.

3 Perkara. Dan lagi Rangga boleh memoetoeskan perkara adat orang melajoe jang mana tinggal di dalam Mento ${ }^{\varsigma}$.

4. Perkara Maka Rangga di koewasakan boewat atawa kerdja parit dan tarima timah deri parit dan timah tiban jang orang mesti antarkan die Mento ${ }^{\varsigma}$.

5 Perkara. Maka Rangga sama kapala ${ }^{2}$ di Mento ${ }^{\varsigma}$ boleh memboewat parit atawa menggali batoe timah dengan belandja dia sendiri di atas dia poenja kaoentoengan boleh djoewal sendiri di mana dia poenja soeka.

6 Perkara. Lagi Rangga boleh dapat koeli orang Bangka dari patih saben ${ }^{2}$ hari 12 orang boewat angkat segala kerdja.

7 Perkara. Segala poetoesan adat orang Bangka jang besar maoe di sembahkan kapada Soeltan Palembang tetapi dahoeloe mesti di masokkan kapada Rangga di Mento ${ }^{\varsigma}$.

8 Perkara. Maka di dalam satoe tahoen atawa tiga tahoen itoe Rangga mesti mengadep di Palembang djoega boleh lebeh lekas djikalaw ada pekerdjaan jang perloe.

9 Perkara. Di larangkan keras tiada boleh satoe radja ${ }^{2}$ atawa mantri dan lain ${ }^{2}$ bangsa orang Palembang berkawin dengan orang Mento ${ }^{\varsigma}$ jang asal dari Wan Awang melainkan sadja siapa jang djadi Soeltan

10 P'erkara. Itoe Rangga djikalaw dia masok Palembang dia poenja prahoe boleh masok berlaboeh di pangkalan dalam dengan tiada oesah mengadep kapada lain mantri melainkan dia boleh teroes kapada Baginda Soeltan. 
INSTRUCTIE VOOR DE PATIH'S, DE BATIN-PASIRAH'S EN DE BATIN-PENGANDANG'S OF BATIN-KETJIL.

1 Perkara. Segala patih atawa batin-pasirah dan batin ${ }^{2}$ tanah Bangka tiada boleh djadi melainkan dapat idin dari Soeltan Palembang.

2 Perkara. Maka itoe patih, batin pasirah dan batin ${ }^{2}$ masing ${ }^{2}$ dengan orangnja jang di bawahnja sendiri ${ }^{2}$ dan itoe patih djadi pasirah di atas batin-pengandang dan batin-pasirah mendjadi pasirah batin-pengandang.

3 Perkara De temtoekan tiap ${ }^{2}$ kapala jang terseboet di dalam satoe tahoen atawa tiga tahoen datang mengadep kapada baginda Soeltan Palembang menjatakan segala hal tanah Bangka tetapi dia boleh datang lebeh dahoeloe dari waktoe jang terseboet djikalaw ada pekerdjaan jang perloe.

4. Perkara. Maka segala orang jang djadi koeli atawa matagawe dan jang mengaloewarkan timah tiban satoe potong satoe orang' itoe melainkan orang Bangka jang soedah berbini tetapi djikalaw soedah bertjerei atawa soedah bermantoe dengan sebab itoe djadi loepoet di atas segala pekerdjaan jang terseboet serta soedah di temtoekan jang perampoewan tiada boleh kaloewar dari tempatnja masing ${ }^{2}$ distriknja kendiri ${ }^{2}$.

5 Perkara. Patih, batin-pasirah, batin-pengandang dan gegading dan lengan di temtoekan dia dapat toeloengan dari dia poenja orang masing ${ }^{2}$ memboewatkan ladang patih dapat 10 hari tiap ${ }^{2}$ satoe orang jang soedah berkawin di dalam satoe tahoen dan batin-pasirah demikian itoe djoega melainkan batin-pengandang tjoema dapat lima hari di dalam satoe tahoen gegading atawa lengan dapat satoe hari di dalam satoe tahoen-padi. 
6 Perkara. Tetapi djikalaw ada jang tiada kaloewar mengerdjakan itoe maka di hitoeng berapa hari² jang dia tiada kerdja di soeroh bajar dengan padi atawa dengan taksir satengah roepiah satoe hari.

7 Pekara. Demikian lagi kapala ${ }^{2}$ jang terseboet dia dapat toeloengan dari orangnja memboewatkan roemah dan balai di dalam kampoeng kapalanja.

8 Perkara. Maka sekalian orang jang boedjang di lepaskan dari segala pekerdjaan melainkan djikalaw ada pekerdjaan pesoerohan negri dia mesti kena kerdja djoega.

9 P erkara. Djikalaw satoe tjina pakai satoe perampoewan Bangka boewat goendik maka itoe tjina mesti bajar saben ${ }^{2}$ satoe tahoen 10 ringgit atawa roepiah 33 kapada kapalanja.

10 Perkara. Djikalaw melajoe atawa lain ${ }^{2}$ bangsa dari orang Bangka jang maoe berkawin dengan perampoewan Bangka dia mesti membajar wang persembah kapada kapalanja 26 ringgit dan mas-kawin 5 ringgit kapada itoe perampoewan atawa bapanja tetapi di katjoewalikan jang itoe orang melajoe dari segala pekerdjaan radja dan negri melainkan pekerdjaan perang atawa berkelahi itoe dia poenja bahagian tetapi kapala tiada boleh dapat bajaran wang persembahan djikalaw orang Bangka samanja Bangka jang berkawin melainkan itoe perampoewan jang dapat mas-kawin.

11 Perkara. Djikalaw satoe orang maoe bertjerei maka lebeh dahoeloe laki^ bajar satengah roepiah dan perampoewan bajar satengah roepiah kapada kapalanja maka beroleh laki² loepoet dari pekerdjaan koeli tetapi djikalaw dapat tahoe dia bertjerei itoe poera ${ }^{2}$ sebab maoe meloepoetkan dari pekerdjaan maka di denda 12 ringgit laki ${ }^{2}$ di soeroh djadi koeli kombali dan itoe denda di bagaikan doewa kapada kapalanja satoe bagian dan satoe bagian kapada mandoernja.

12 Perkara. Maka segala poesaka orang mati jang tiada waritz atawa maski ada waritznja tetapi tinggal di bawah lain kapala maka itoe poesaka dapat kapada siapa jang djadi kapalanja di tempat jang mati tetapi djikalaw ada orang mati tiada poenja belandja tanam maka itoe kapala kaloewar belandja tanamnja.

13 Perkara. Djikalaw segala barang jang baroe atawa benda ${ }^{2}$ dapat di laoet atawa di darat maka barang bagitoe di bahagi doewa satoe bahagian kapada kapalanja dan satoe bahagian kapada jang meudapat. 
14 Perkara. Djikalaw orang lain proatin masok berladang di dalam lain kapala poenja watas atawa tanah maka berapa perolehnja ladang di bahagi 4 kapada jang poenja tanah satoe bahagian dan jang 3 bahagi orang jang menoempang lagi jang menoempang menoeloeng kerdja di dalam itoe tanah tempat dia berladang di dalam berapa lama tempoh kerdja.

15 Perkara. Segala roepa djikalaw orang poenja niat kapada kapalanja atawa kapada keramat djikalaw tida di sempornakan di denda dari 6 sampei 12 ringgit saparoh kapada kapalanja dan lain kapada orang banjak.

16 Perkara. Segala hoekoem adat jang dapat hoekoemannja mati dapat poetoes oleh Soeltan jang bagimana di temtoekan melainkan itoe hoekoeman bertjampoer oegama itoe dapat poetoes kapada kapala di Mento ${ }^{5}$ dengan idin Soeltan.

17 Perkara. Maka segala poetoesan denda jang lebeh dari 24 ringgit di atas koewasa patih dan pasirah tetapi dia boleh djoega memoetoeskan perkara jang lebeh ketjil djikalaw sebab orangnja sendiri atawa batin-pengandang poenja permintaan atawa sebab ia anggan memoetoeskan.

18 Perkara. Maka tiap² batin-pengandang tiada koewasa memoetoeskan segala hoekoem jang lebeh deri 24 ringgit dan tiada boleh memoetoeskan hoekoeman jang lebeh ketjil djikalaw orang poenja perkara ada saparoh di bawah pasirah poenja parentah.

19 Perkara. Segala poetoesan patih batin-pasirah djikalaw orang rasa berat atawa tiada betoel dia orang boleh minta datang sendiri kapada Soeltan di Palembang djikalaw denda perkara bertjampoer dengan oegama dia boleh minta datang mengadep kapada Rangga di Mentos.

20 Perkara. Perkara jang soembang bernama boejoeng atawa soembang sebab main soendal kapada sanaknja jang tiada halal nikah hal jang demikian itoe dapat hoekoem mati oleh mantri di Mento $^{\varsigma}$ tetapi lebeh dahoeloe dapat idin dari Soeltan Palembang.

21 Perkara. Maka segala boenoh jang boekan sengadja atawa sebab panas hati atawa sebab orang bertjerei dengan bini dalam boenting maka tiada di sempornakan makanannja dan obatnja oleh lakinja tadi maka djadi mati hal demikian itoe lakinja di denda 120 sampei 424 ringgit namanja pembangoen dapat kapada waritznja jang mati. 
22 Perkara. Berkelahi dengan sendjata atawa tida sendjata maka sebab itoe menjatjatkan di denda dari 16 sampei 32 ringgit dapat kapada jang mendawa ja-itoe jang tjatjat.

23 Perkara. Djikalaw soewatoe membinasakan poehoen ${ }^{2}$ atawa kebon" di soeroh ganti harga bagimana taksirnja itoe poehoen di tempat itoe tetapi djikalaw njata dengan sengadjanja soedah boewat lagi di denda dari 20 sampei 200 ringgit kapada kapalanja itoe denda.

24. Perkara. Djikalaw mentjoeri barang jang tersimpan atawa tanam itoe barang di kombalikan kapada jang ampoenja apa jang koerang di ganti dengan bergenda harganja lagi dapat denda dari 24 sampei 44 ringgit kapada kapalanja saparoh dan kapada jang poenja barang saparoh.

25 Perkara. Djikalaw orang mentjoeri madoe soenggoe atawa sijalang atawa papah dahoeloe soeroh ganti bagimana di taksir berapa kaloewar madoe dan lilinja denda 10 sampei 55 ringgit.

26 Perkara. Mentjoeri poekat atawa ikan dari tempat orang poenja peroesahan kena denda dari 10 sampei 48 ringgit apa jang koerang mesti di ganti.

27 Perkara. Djikalaw mengamar maoe memboenoh atawa membakar roemah atawa lain boewat orang poenja tjelaka kena denda 6 sampei 26 ringgit kapada kapalanja jang dapat.

28 Perkara. Hoekoeman boejoeng pemali atawa boejoeng singgoel, djikalaw satoe orang main soendal dengan perampoewan" jang haroes nikah tetapi pangkatan $\mathrm{ma}^{\varsigma}$ sampei di atas atawa kebawah atawa sebab berakoe ${ }^{2}$-an maka kena hoekoeman 3 bahagian dari ampat kapada kapalanja dan satoe bagian dari ampat di bagi kapada orang banjak di kampoeng mendjadi penawar baroe itoe perampoewan sama $\mathrm{laki}^{2}$ itoe boleh berkawin.

29 Perkara. Pengangkat djikalaw orang soedah main soendal sama lain orang poenja bini sebab itoe soedah djadi terang maka itoe laki ${ }^{2}$ kena pengangkat dari 72 sampei 148 ringgit satoe bahagian dari ampat dapat kapada kapalanja tetapi djikalaw itoe perampoewan di hoekoemkan menoeroet laki jang maka kapalanja tiada dapat bagian melainkan dapat kapada jang poenja bini dan lagi itoe perampoewan tiada boleh dapat satoe apa ${ }^{2}$ harta dari lakinja melainkan djikalaw lakinja soeka membri dengan soekanja dan pikoel segala oetang laki jang lama melainkan djikalaw bertjerei sebab lakinja boewang di bagi doewa segala harta dan segala pioetang. 
30 Perkara. Palirang basah saperti laki ${ }^{2}$ bermain soendal dengan perampoewan jang haroes nikah sampei djadi boenting maka dia orang tida maoe berkawin maka di denda kapada siapa tida maoe berkawin dari 16 sampei 26 ringgit dapat kapalanja tetapi djikalaw perampoewan maoe berkawin itoe laki ${ }^{2}$ tida maoe maka itoe denda dapat kapada perampoewan tetapi boleh lepas denda jang terseboet djikalaw dia berkawin kadoewanja dengan soekanja melainkan bajar 6 roepiah kapada kapalanja tetapi djikalaw ia berkawin itoe dengan di peksa maka tida boleh hilang denda jang terseboet tadi dendanja saparoh dapat kapada perampoewan dan saparoh kapada kapalanja itoe pon djikalaw itoe perampoewan soeka dengan tida di peksa tetapi djikalaw komedian dengan di peksa samoewanja dapat kapada kapalanja.

31 Perkara. Palirang kering djikalaw satoe orang soedah kaloewar soewara kapada orang poenja anak bini atawa kapada orang boedjang dengan perkataan maoe kapadanja dengan hal kerdja jang kedji maka kena denda 3 sampei 12 ringgit kapada jang mendawa dapat tetapi djakalaw anak atawa bini kapalanja di denda deri 12 sampei 24 ringgit.

32 Perkara. Singgoel djikalaw satoe orang masok di dalam roemah perampoewan dengan tida boewat satoe kedjahatan tempoh iboe bapanja sanak soedaranja tida ada di roemah maka di denda 4 sampei 6 roepih demikian lagi orang datang di roemah orang dengan tida permisi jang ampoenja roemah lantas berbaring tiarap di dalam itoe roemah dan djoega kena denda 4 sampei 6 terkadang jang ampoenja roemah kena djoega dia tahoe itoe orang baroe datang belom lagi pergi di balai maka dia berani tarima itoe orang di dalam roemah.

33 Perkara. Pemandian kesarangan djikalaw satoe laki ${ }^{2}$ pergi di tempat mandi di kampoeng atawa di loewar kampoeng tempat dekat itoe ajer tida berterejak maka sebab itoe dia ketemoe dengan perampoewan mandi bertelandjang kena denda 6 sampei 12 kapada jang mendawa tetapi djikalaw ada satoe tanda jang itoe laki² soedah berterejak ada bekas ${ }^{2}$ dia bernanti di loewar pemandian maka ja-itoe lepas dari denda jang terseboet.

34 Perkara. Temboeng lakoe djikalaw satoe orang bekin hoeroe hara dengan moeloet atawa kalakoewan atawa dengan lain ${ }^{2}$ hal sebab djadi satoe ketjideraan atawa kemaloewan di dalam 6e Volgr. I. 
itoe kampoeng dengan sebab itoe hal maka di denda 2 sampei 24. tiga bagian kapada jang mendawa satoe bagian kapada kapalanja di sitoe.

35 P erkara. Pengoewat djikalaw satoe perampoewan jang soedah bertoenangan dengan satoe laki² komedian tida djadi maka itoe perampoewan moengkir djadi kawin dengan lain orang maka djikalaw itoe perampoewan tida djadi berkawin kapada toenangan lama dengan sebab laki² jang kadoewa poenja perboewatan dan akal itoe laki ${ }^{2}$ di denda 2 sampei 24 saparoh kapada jang poenja toenangan dan saparoh kapada kapalanja.

36 Perkara. Pengangkat tempoh andeinja ada penjakit keras atawa sebab binatang boewas di dalam kampoeng maka ini kampoeng belom sampei itoe perkara maka itoe kampoeng jang belom kena penjakit di beri tanda satoe kajoe jang berkoepas di tengah djalan atawa di tengah oetan jang maoe masok di kampoengnja sopaja djangan orang kampoeng jang ada ampoenja penjakit masok di dalam dia poenja kampoeng. Dan bagitoe djoega djikalaw melanggar segala kepertjajaan atawa pentangan jang ketjil ${ }^{2}$ dari dia orang poenja adat maka kena denda 4 sampei 40 ringgit terbahagi kapada segala orang jang di dalam kampoeng.

37 Perkara. Maka segala poetoesan denda jang tida lebeh dari 120 kapalanja boleh peksa sama jang kena denda dengan kerdja saperti boewat abis itoe wang melainkan djikalaw perkara lebeh dari itoe boleh pergi di Palembang atawa di Mento $^{\varsigma}$ kaloe itoe perkara bertjampoer dengan oegama.

38 Perkara. Segala denda jang terseboet orang boleh bajar satoe bagian dari ampat dengan oewang toenei lain dia boleh bajar dengan segala roepa barang dengan harga lebeh tinggi sakali dari taksiran.

39 Perkara. Maka segala perkara pengangkat dendanja kapada jang mendawa atawa waritznja tetapi boleh djoega kapalanja dapat djikalaw itoe perkara bertjampoer dengan boejoeng atawa pemali.

40 Perkara. Boejoeng pemali samowanja kapala jang dapat tetapi saparoh itoe wang dia mesti bagikan tepoeng tawar didalam kampoeng samowanja orang boleh dapat makanan dari itoe penawar.

41 Perkara. Maka segala denda pembangoen orang mati kapalanja dapat satoe bagian dari tiga di katjoewalikan itoe 
pembangoen itoe perkara kajoe $^{2}$-an atawa poehoen ${ }^{2}$ segala denda mentjoeri itoe harta kapalanja dapat satoe bagian dari lima dan palirang basah terkadang kapalanja dapat dan ada jang tida dan segala temboeng lakoe pengangkat kapalanja dapat satoe bagian dari tiga.

42 Perkara. Piawang petjah djikalaw kapalanja melanggar oendang jang terseboet kena hoekoem terlipat dari segala denda kapada jang mendawa serta di bagikan satengah segala orangnja segala denda jang kapalanja tida dapat tetapi dia dapat wang memoetoes 2 roepiah sampei 12 di bahagi dengan orang di bawahnja jang memoetoeskan perkara itoe.

43 Perkara. Segala denda jang kapalanja dapat mesti di bahagi tiga sama kapalanja jang di bawah dan orang toewa ${ }^{2}$ jang bersamaan memoetoeskan hoekoem tetapidjikalaw pasirah poenja orang jang di bawah dia sendiri bahagi tiga tetapi satoe bahagian kapada orang di bawahnja dan lain kapada pasirah samoewanja melainkan djikalaw pasirah memoetoes perkara orang dari batin-pengandang maka itoe di bahagikan doewa satengah kapada batin dan satengah kapada kapala dan bagitoe lagi djikalaw batin dapat bahagian dari dia poenja poetoesan sendiri mesti di bahagi tiga satoe bahagian kapada itoe mandoer ${ }^{2}$ dari orang jang salah jang lain kapada batin.

44. Perkara. Maka segala oendang adat jang terseboet itoe tjoema kapada segala orang Bangka tetapi di katjoewalikan kapada orang melajoe jang tinggal di Mento ${ }^{\varsigma}$ maski djoega orang melajoe jang tinggal di bawah pasirah atawa batin djikalaw di dalam perkara oegama dia boleh anggan dari poetoesan adat Bangka jang terseboet djikalaw ia maoe minta poetoesan oegama di Mento 5 .

45 Perkara. Demikian soedah di temtoekan oleh baginda Soeltan segala hal dan ahwal jang terseboet kapada Rangga dan Patih $^{2}$ dan Pasirah di tanah Bangka samoewanja. 